\title{
USING VALUE ASSESSMENT AS A TOOL FOR SAFEGUARDING BUILT HERITAGE "THE CASE STUDY OF EMPRESS MARKET IN KARACHI"
}

\author{
Tania Ali Soomro* \\ Mohsin A. Soomro**
}

\begin{abstract}
Understanding and documenting the value of a heritage property is of utmost importance. The value of built heritage is basically referred to as an intangible aspect that characterizes its importance, worth, usefulness or the benefits in various dimensions. Heritage is valued not as an intellectual enterprise but it also plays instrumental, symbolic, and other functions in society (Tidwell, 2002). This research paper focuses on analyzing the historical and architectural value of Empress Market building in Karachi, which in 1995 was declared protected heritage of Pakistan. To understand the worth of the building and authenticity of that worth, a value based analysis is carried out with the help of applying Nara Grid to its various aspects. Nara grid is an evaluation scheme that helps measure authenticity of a building. A historical timeline of the building has been developed to understand the complexity of the structure. To gain a better understanding of the building, the architectural value assessment is carried out on the basis of research, architectural works, construction techniques and the structural systems. It also includes an inventory of the significant architectural attributes.
\end{abstract}

Keywords: Value assessment, built heritage, Empress Market, Karachi

\section{INTRODUCTION}

Value assessment is an elementary instrument to apprehend the substance of any building. It aids to prioritize the conservation efforts, as limited resources put constraint on the magnitude of efforts. The notion of value is tough to express in measurable terms it is an intangible aspect that is associated with the structure. It may be discouraging to signify the value in economic or financial terms only, as there are numerous attributes of values such as cultural, historic, economic, political and aesthetic, that a building can possess which may change over time, overlap or be contested. The values are strongly molded by the contextual factors of the place where the buildings exist and may differ from one another.

The prime purpose of this paper is to know how the value of a built heritage can be defined, and in this order the building of Empress Market; which bestows a characteristic elegance of a domestic Indo-Gothic Style has been selected as a case study. The value network of the market is broken down into layers, that has assisted to comprehend the present state of the building with respect to its form, design, material and present occupancy.

\section{Empress Market - A Case Study}

The Empress Market building in Karachi was designed in a symmetrical manner around an open to sky courtyard by James Strachan, the Municipal Architect then in 1889. It is situated in one of the eighteen historic towns of the present day city in zone Karachi-south. Its location in the heart of the city of Karachi makes it an outstanding monument, easily accessible in terms of both private as well as public transportation. The main entrance space serves as a vestibule that further provides connection to the other wings via huge pointed arched opening. It further opens up into an open terrace that connects it to the courtyard. The entrance is flanked by a 140' high clock tower which is accessed through a spiral metal staircase, that ends up in the open terrace (Figure 1). The façades of the building are punctured at regular intervals to provide window openings and are decorated with the twin pilasters. Following the characteristic of a Gothic form, entire series of doors and windows have pointed openings. The façade adornment is done in similar manner for both outside as well as the façades facing courtyards except for the number of window openings. Initially each of the wings of the market building was

* Architect Tania Ali Soomro, Lecturer, Department of Architecture and Planning, Dawood University of Engineering \& Technology

Email correspondence: architect.tania@gmail.com

** Dr. Mohsin A. Soomro, Assistant Professor, Civil Department, Quaid-e-Awam University

Email correspondence: drmohsin@quest.edu.pk 


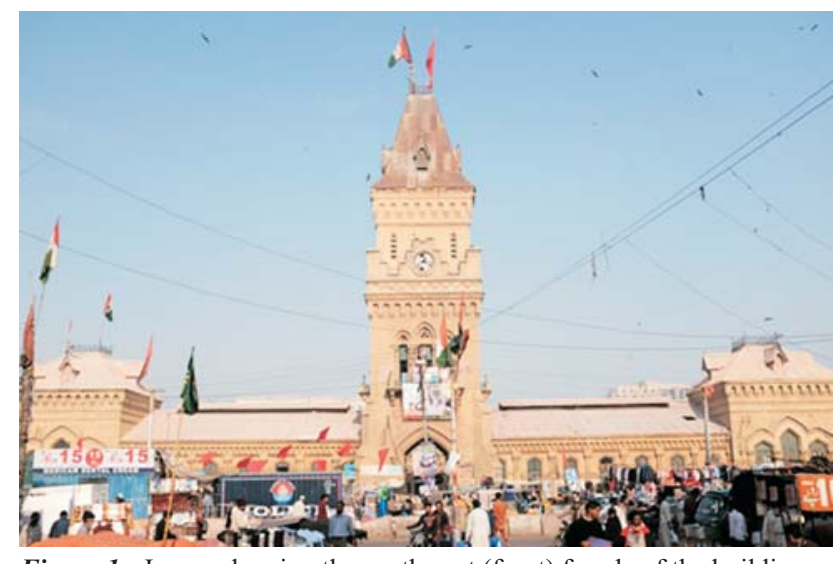

Figure 1: Image showing the south-east (front) facade of the building.

dedicated to separate functions, such as the egg and butter section, mutton section, beef section, bread and grocers section, fruits and vegetables sections. Even today most of the functions exist, but a lot of new shops have been introduced without taking care of the section margins. At each four corners of the building Strachan provided square chamber like rooms, slightly bigger in the space and height as compared with the rest of the wing. According to an interview with Architect Altaf Hussain (Site officer at the KMC office of Empress Market), this chamber was exclusively devoted as the 'area for the placement of beef' and was enclosed by the curtains to respect the Hindu customers (Hindus worship the cow as a goddess). Strachan not only designed the building following the technical and aesthetical design principles, but the ethical value of all the ethnic groups were also considered.

Figure 2 represents the densified neighborhood context of the market building today. The semi-circular gardens at each of the corner of the building, named as the Empress Gardens have been converted into mini markets. Apart from the markets, the major part of the rest of space is occupied by the roadside vendors. These vendors play a key role in serving the transit population. Empress Market is also a major junction of public busses, thus the area receives a large number of commuters throughout the day.

The British acquired refinement through a kind of evolutionary process of method of construction in Britain, and applied it here in Karachi and facilitated the wide range of individual designs; with Empress Market being one of them. The robustness and the sturdiness of form that the building offers is an indication of structural advancement of the British. The structure of the market building is load

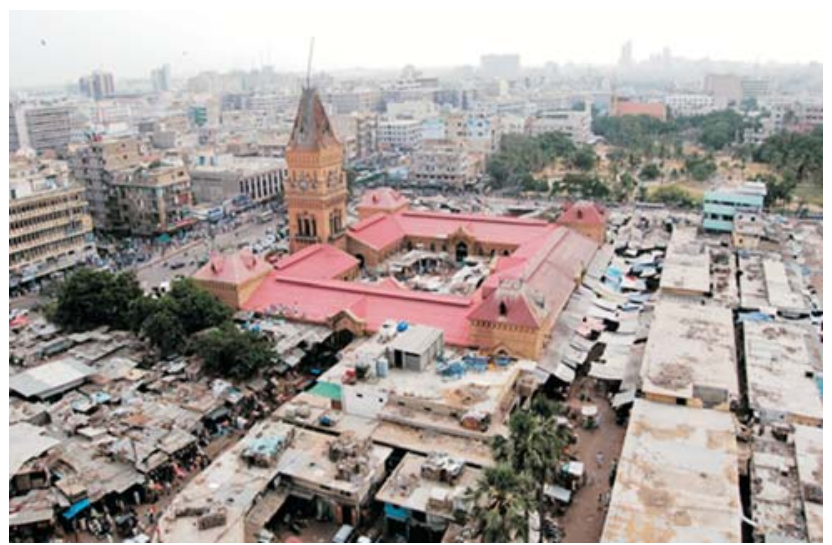

Figure 2: Image showing the aerial view of the market building before the fire damage.

Source: International Design Group, 2011.

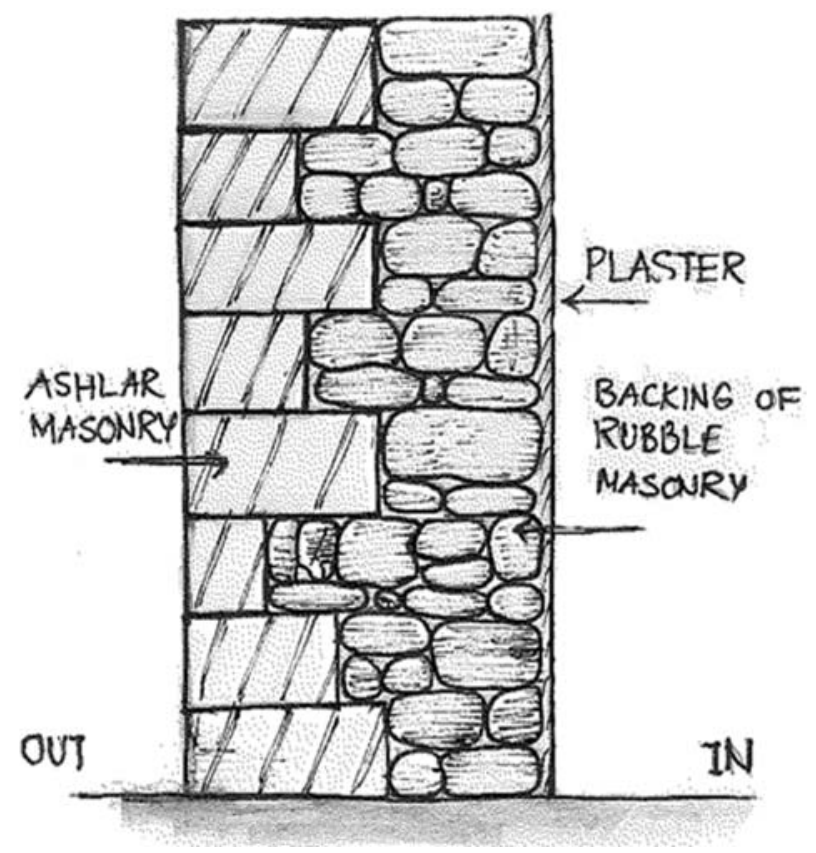

Figure 3: Sketch of the composite wall.

bearing with 20" thick walls, made of Gizri limestone. The external façades of the building have fair finished stones laid in Ashlar masonry whereas the internal surfaces of the walls are plastered with lime (Figure 3).

A comprehensive knowledge about the structure is of utmost importance to evaluate the value system associated with it. Therefore a detailed historical and an architectural study is developed that has assisted in applying the Nara Grid for evaluating the authentic value of the building. 


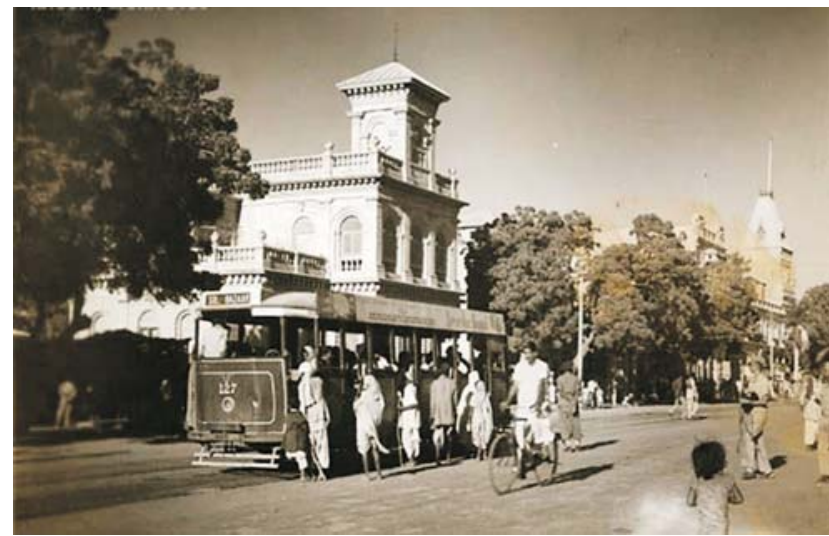

Figure 4: Showing the trams on Preedy Street in front of Eduljee Dinshaw Charitable Dispensary building. Source: Archives 150 - year 1940.

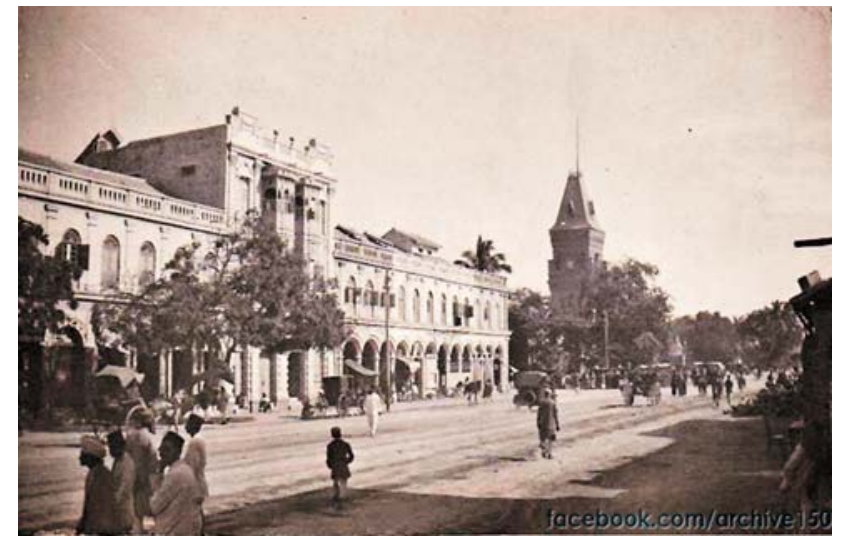

Figure 5: Showing the now demolished historic buildings on Preedy Street namely, Mandviwalla building constructed in 1910 (SB 8/8) enlistment no: 1995-044 and the Biramji building (SB 8/11) enlistment no: 1995 046

Source: Archives 150 - year 1900.

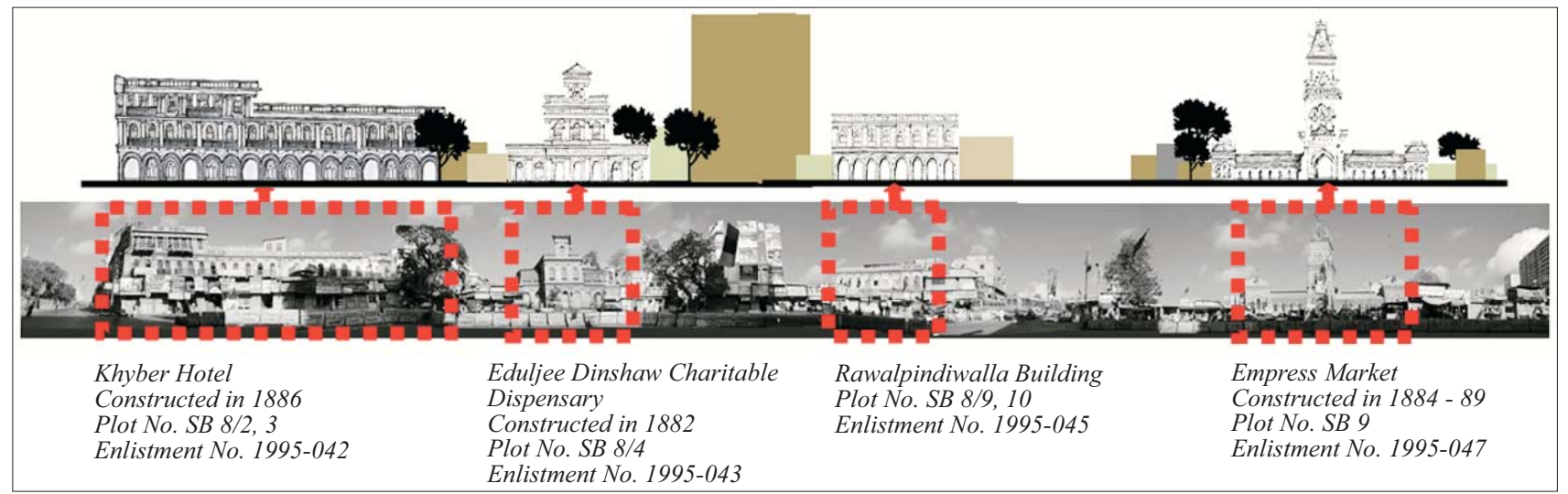

Figure 6: Street montage of Preedy Street showing existing historic properties.

\section{HISTORICAL VALUE - ANALYSIS OF THE CHRONOLOGICAL DEVELOPMENT OF THE BUILDING}

The neighborhood of the market building used to house a number of historic buildings (Figures 4 and 5.) But over time these historic buildings have gone through several changes, including complete destruction and replacement with new structures. Preedy Street, where the Empress Market is situated, remains under constant development pressure, like the rest of the historic cluster of the city. Most of the plots which housed old structures now have high and low rise new structures. Figure 6 shows the street montage of Preedy Street from Empress Market till the building of Khyber Hotel. It clearly illustrates the ratio between the heritage properties and the new construction. Both ends of the street are crowned with the British era buildings. On the south side lays the magnificent Khyber Hotel and to the end of the Preedy Street is situated the glorious building of
Empress Market. As shown in the figure 5 there used to exist two historic buildings namely Mandviwalla building and Biramji building. Both these buildings were declared protected in 1995 and demolished sometime after 1995. This led to the complete change of the landscape and at the moment in this chunk of the Preedy Street there exist only four historic properties (Figure 6).

\section{Study of the Historic Timeline of Empress Market}

The Empress Market was constructed between 1884 and 1889. The Market is remembered as one of the famous and historic structures built in the British Raj era. It evolved from a high class mercantile to a mere whole sale market. The following timeline of the market building apprehends about the decline of the market, and states the causes of decay that led to present situation of the building (Figures 7 and 8$)$. 


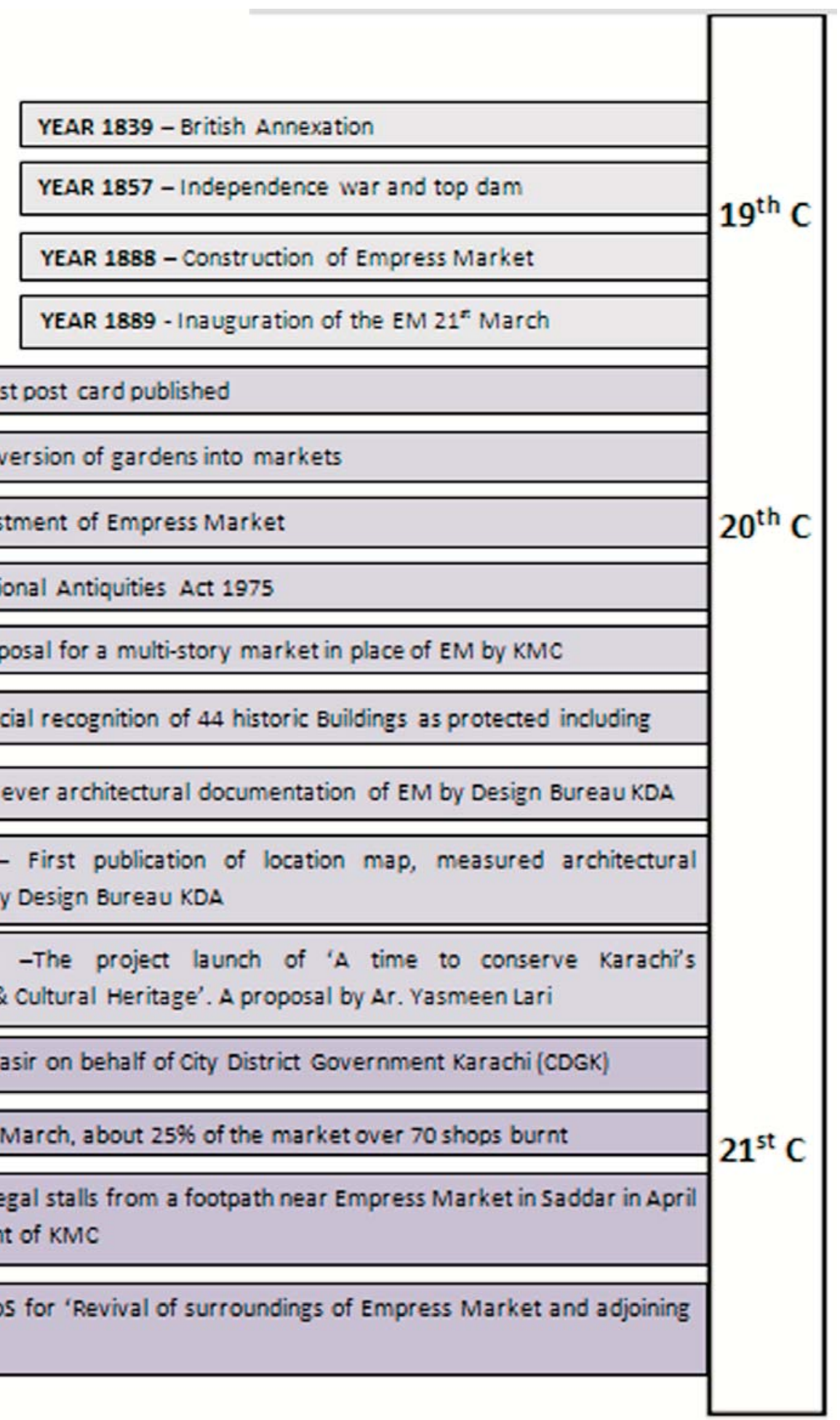

Figure 7: Historical timeline of the Empress Market building. 

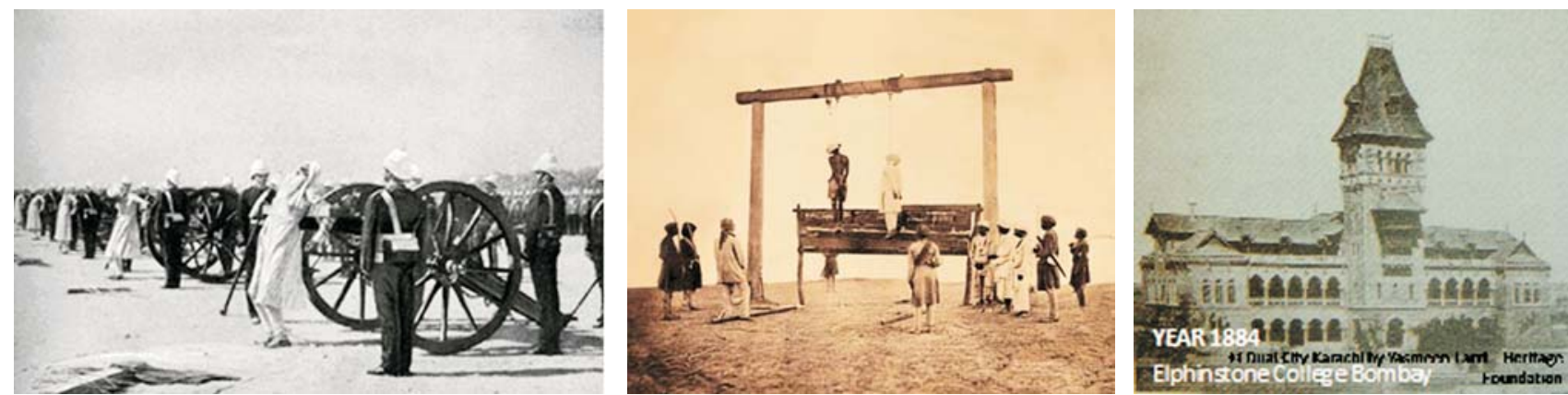

YEAR 1857: Images showing the location of TOPDOM (R) Year 1957

Source: http://www.dostpakistan.pk/wp-content/uploads/2013/05/Top-dam.jpg “accessed 06-06-16".

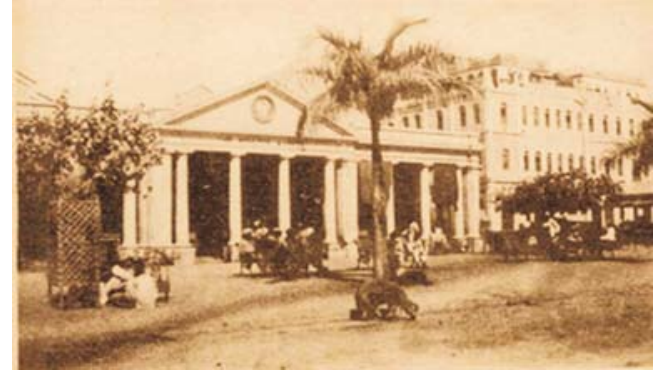

YEAR 1888: Boulton Market Source: Archives 50

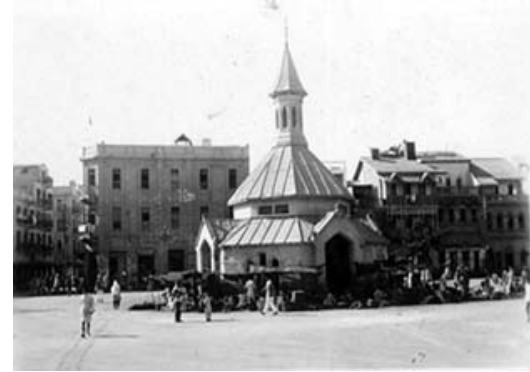

YEAR 1888: Lambert Market Source: Archives 50

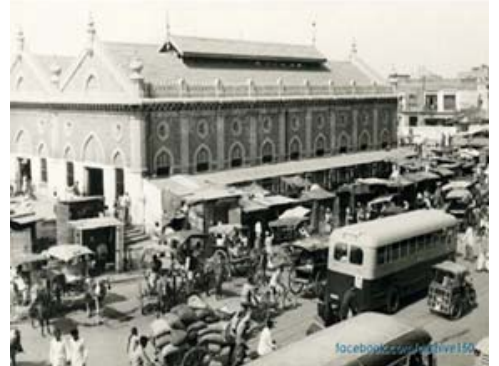

YEAR 1888: Mesham Lea Market Source: Archives 50

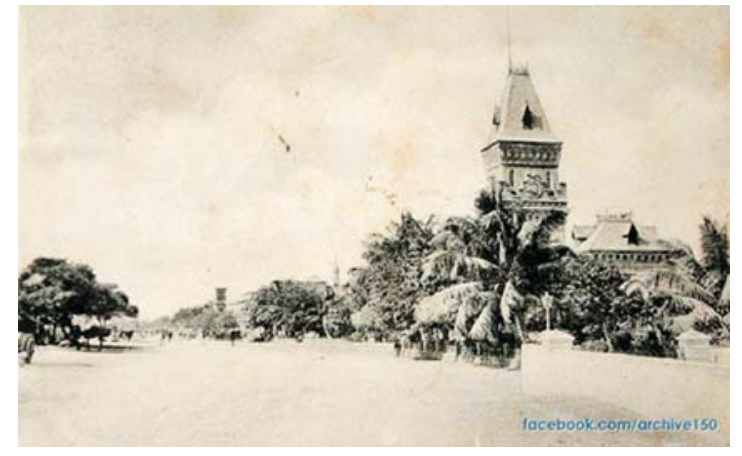

YEAR 1947: Situation of Empress Gardens Source: Archives 50
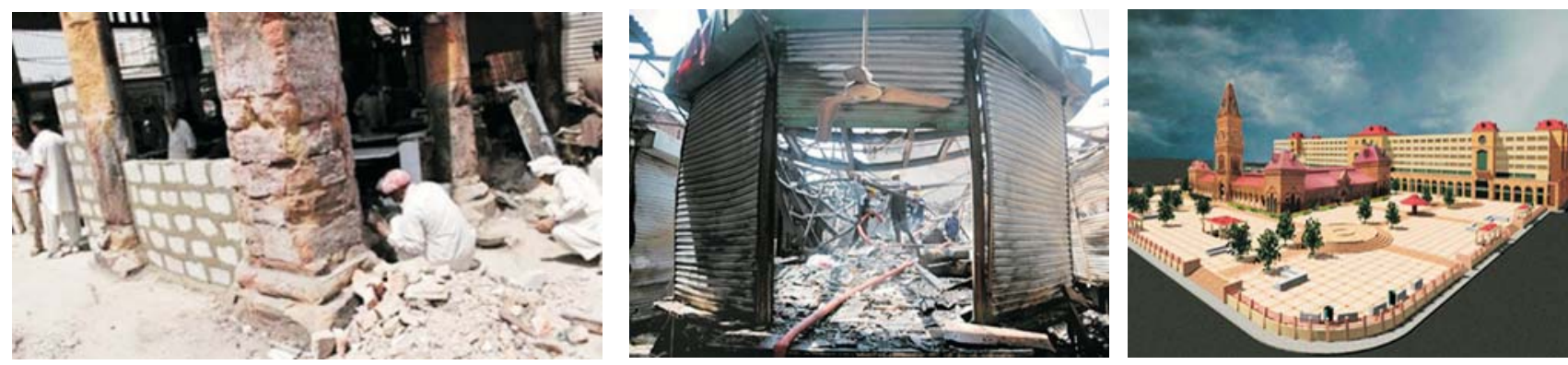

Images showing the fire incident of 2011 and the proposed parking plaza project in 2013 behind Empress maket.

Figure 8: Collection of images describing the timeline of the Empress Market. 


\section{ARCHITECTURAL DOCUMENTATION}

Apart from the architectural drawings a detailed inventory of the significant architectural components of each façade was developed as part of this research. It was developed in the form of a table that not only contained the drawing of the components but also the current image, to have a clear understanding about each component of the building. With the drawing a detailed image and a small description of each component was also added. This inventory was useful in viewing and understanding the craftsman details in the architectural works of the building and to help analyse the building (Figures 9 and 10).

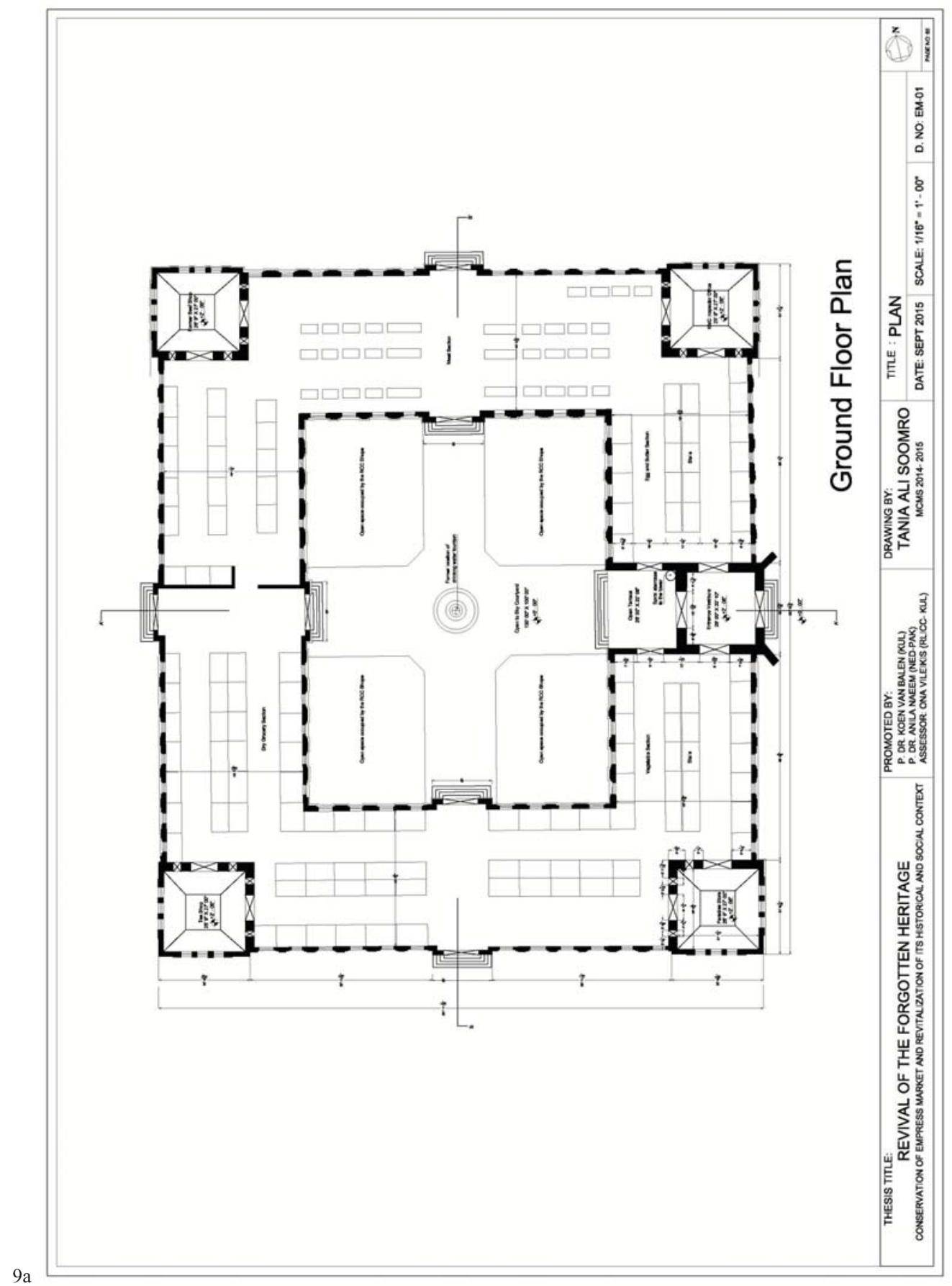




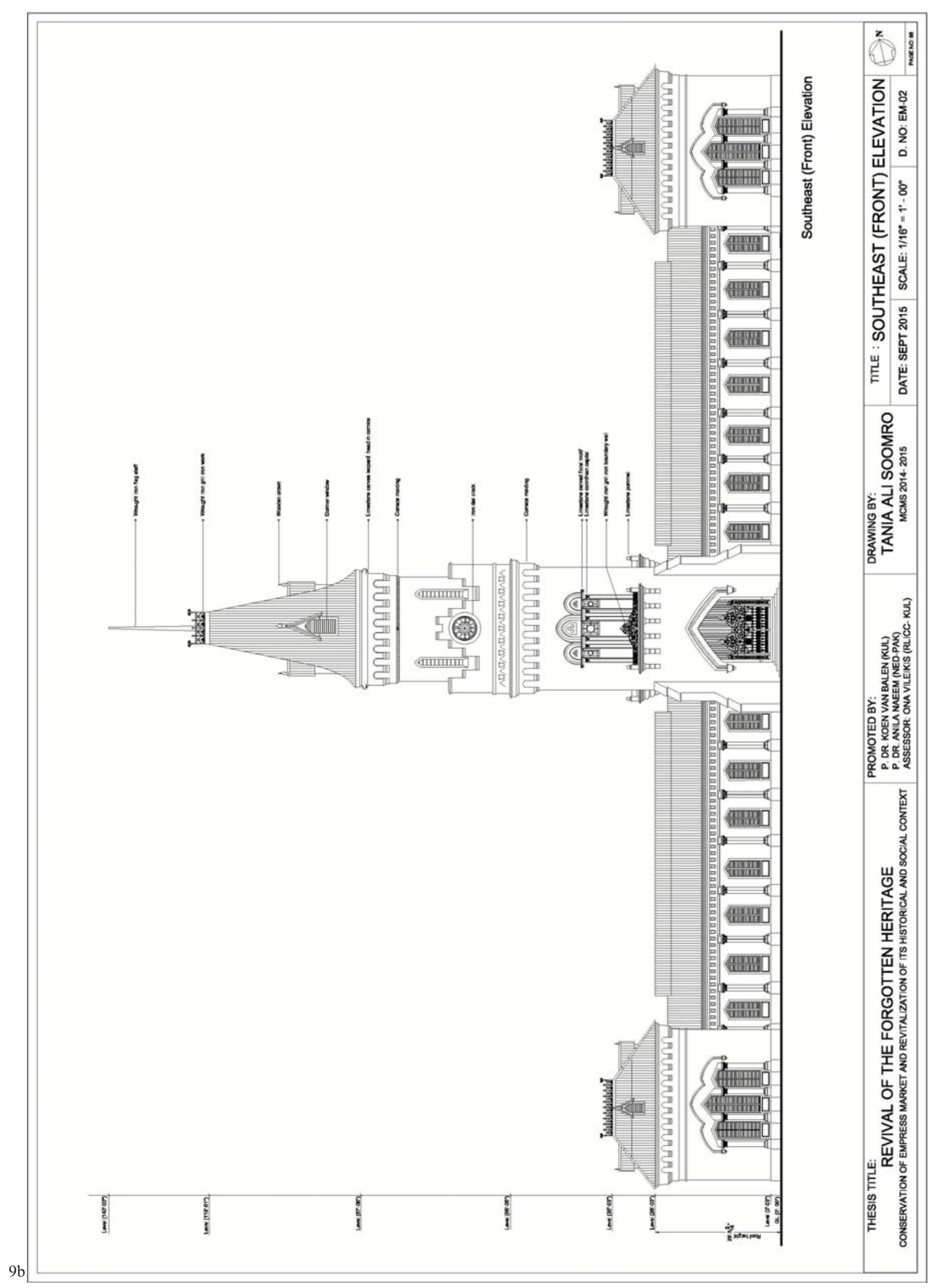

Journal of Research in Architecture and Planning: Vol. 23, 2017 (Second Issue) 


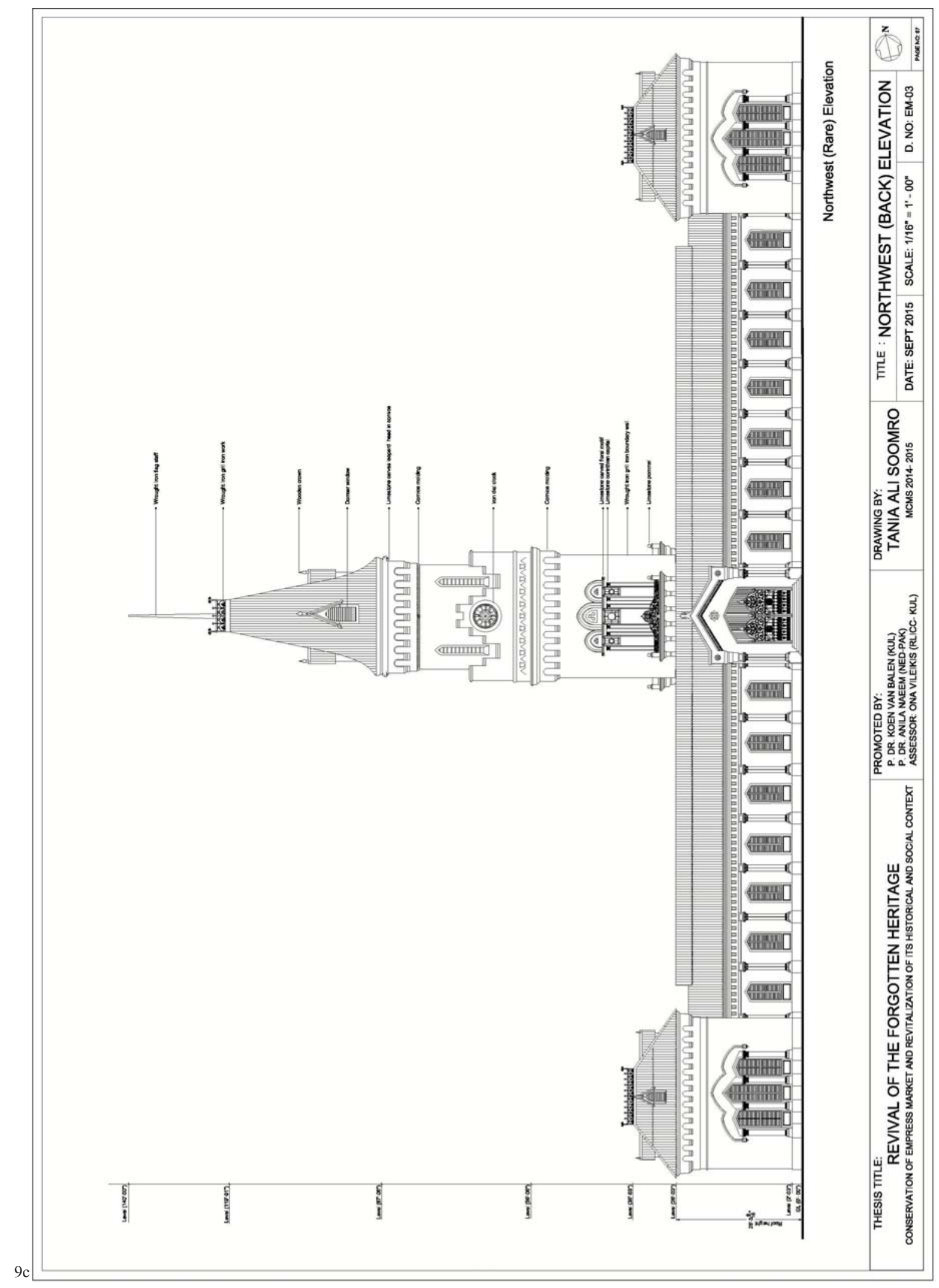




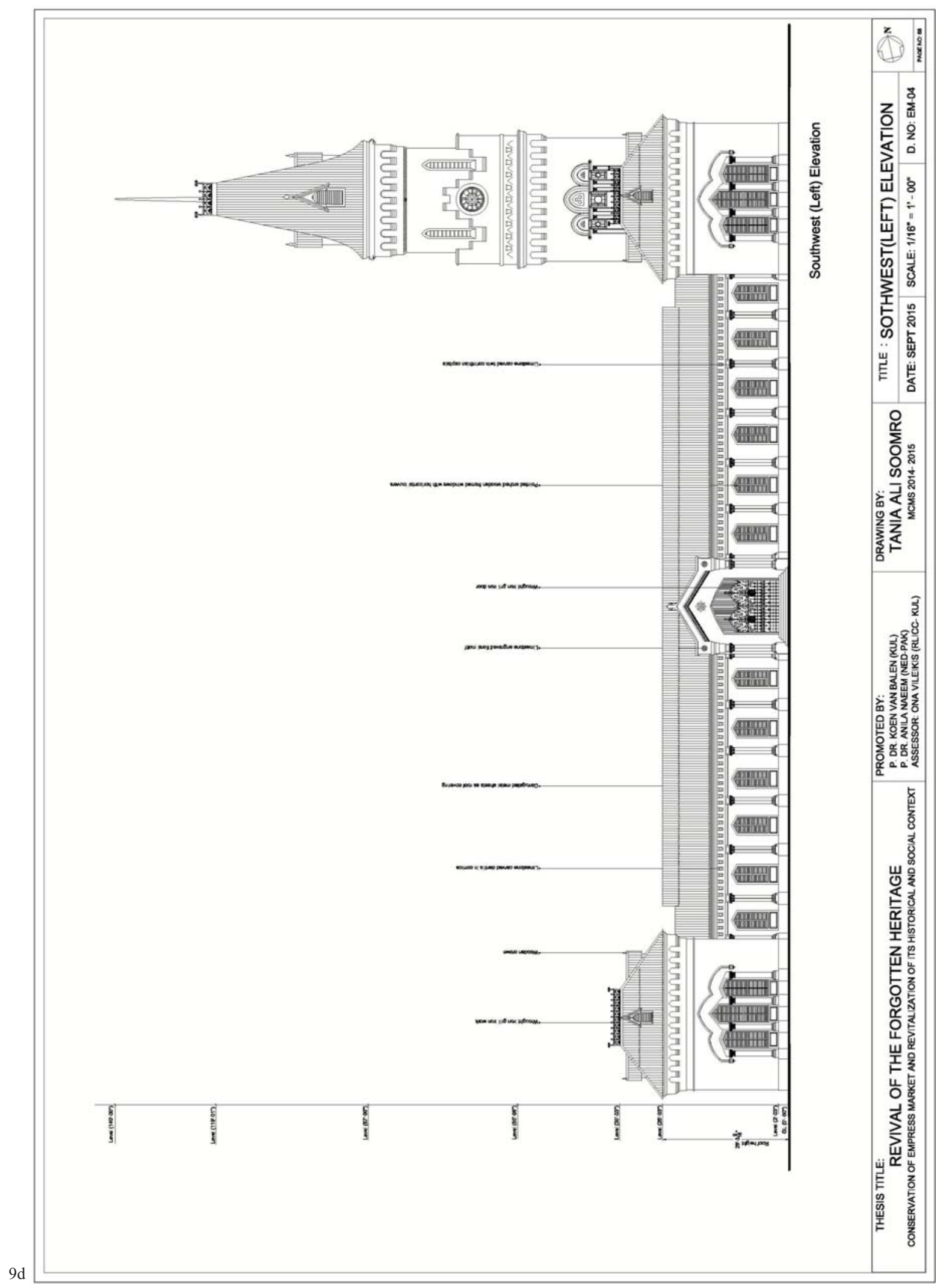

Journal of Research in Architecture and Planning: Vol. 23, 2017 (Second Issue) 


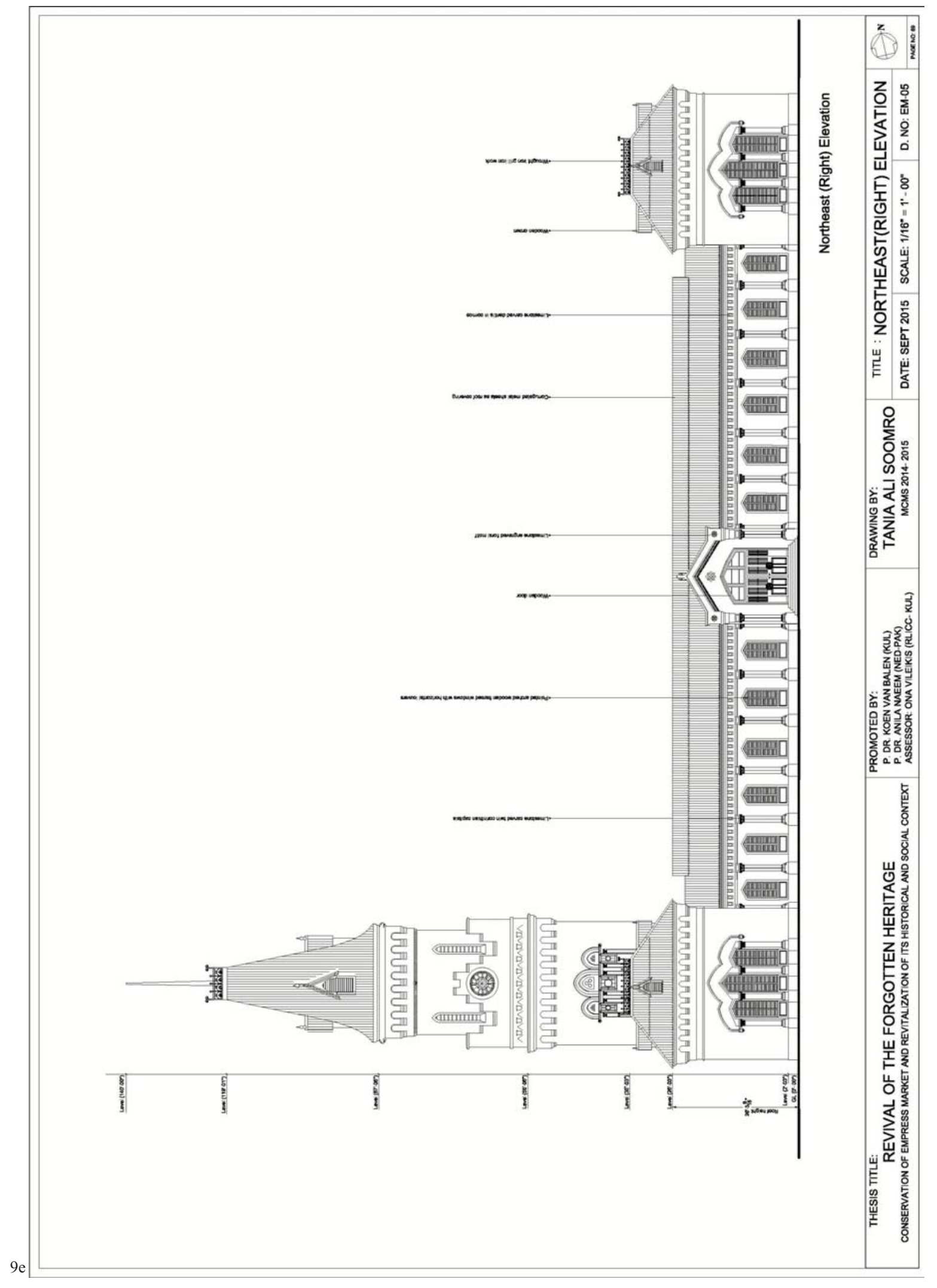




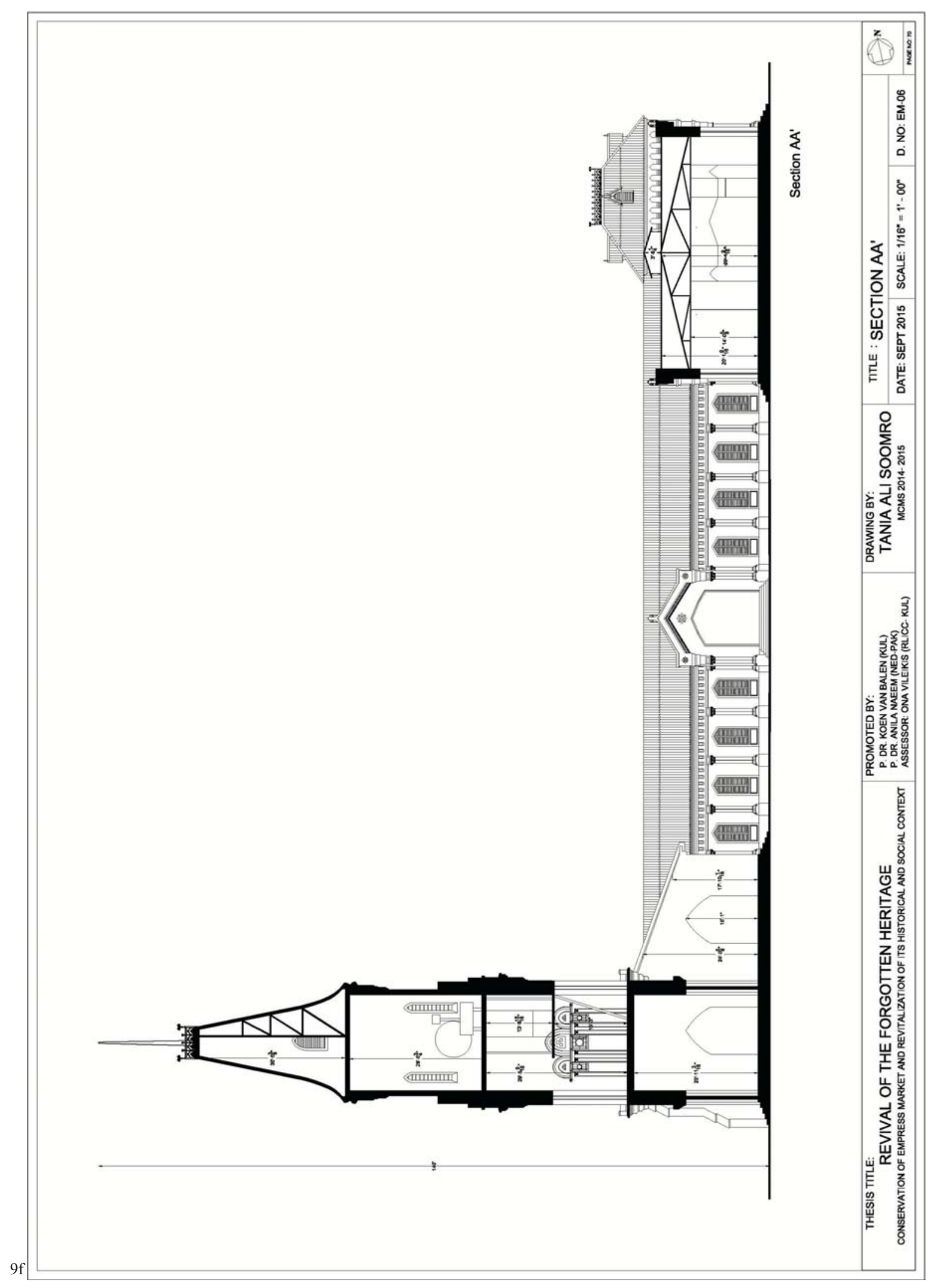

Journal of Research in Architecture and Planning: Vol. 23, 2017 (Second Issue) 


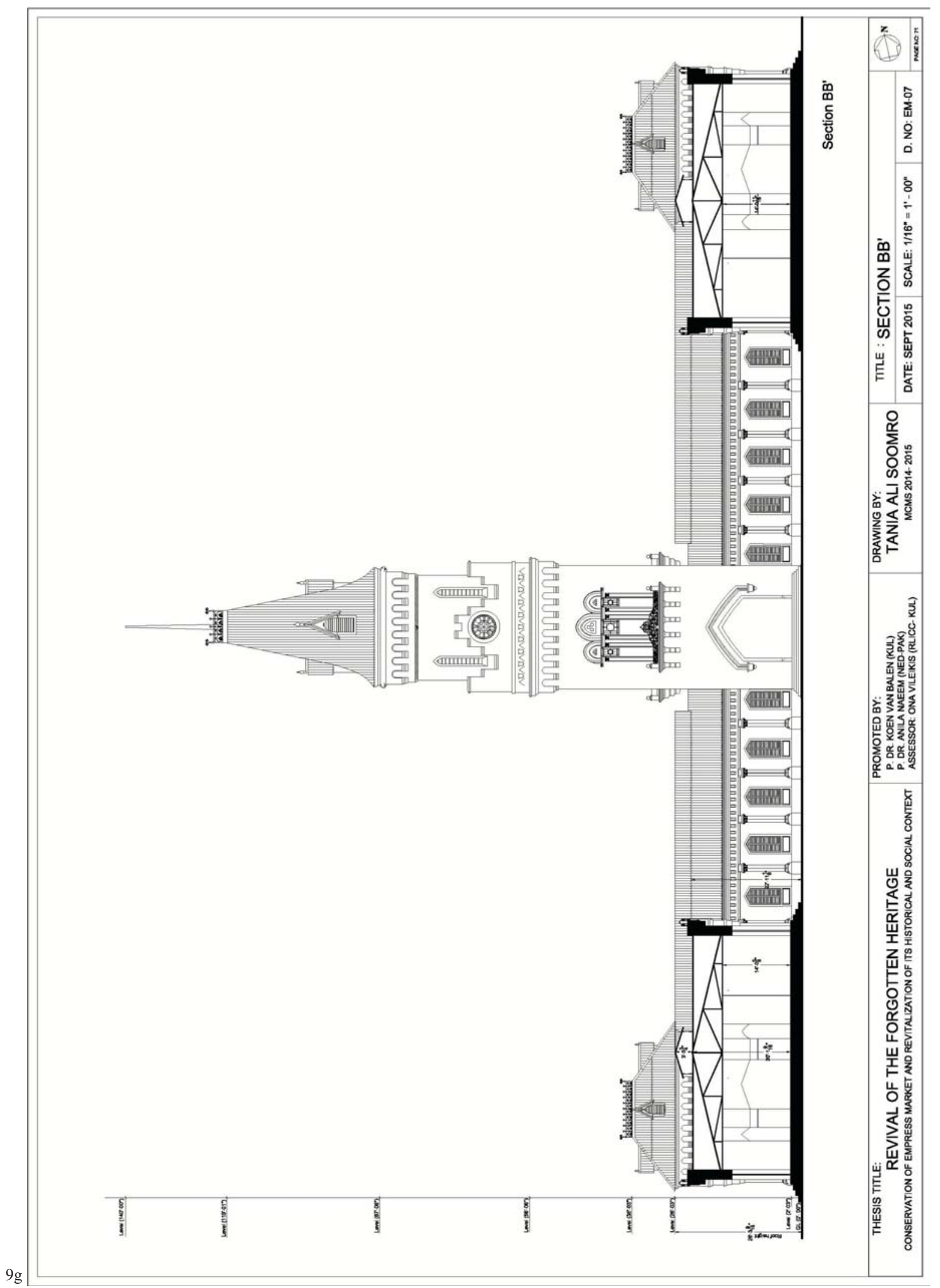

Figure 9(a-g): Architectural drawings of the market building. 


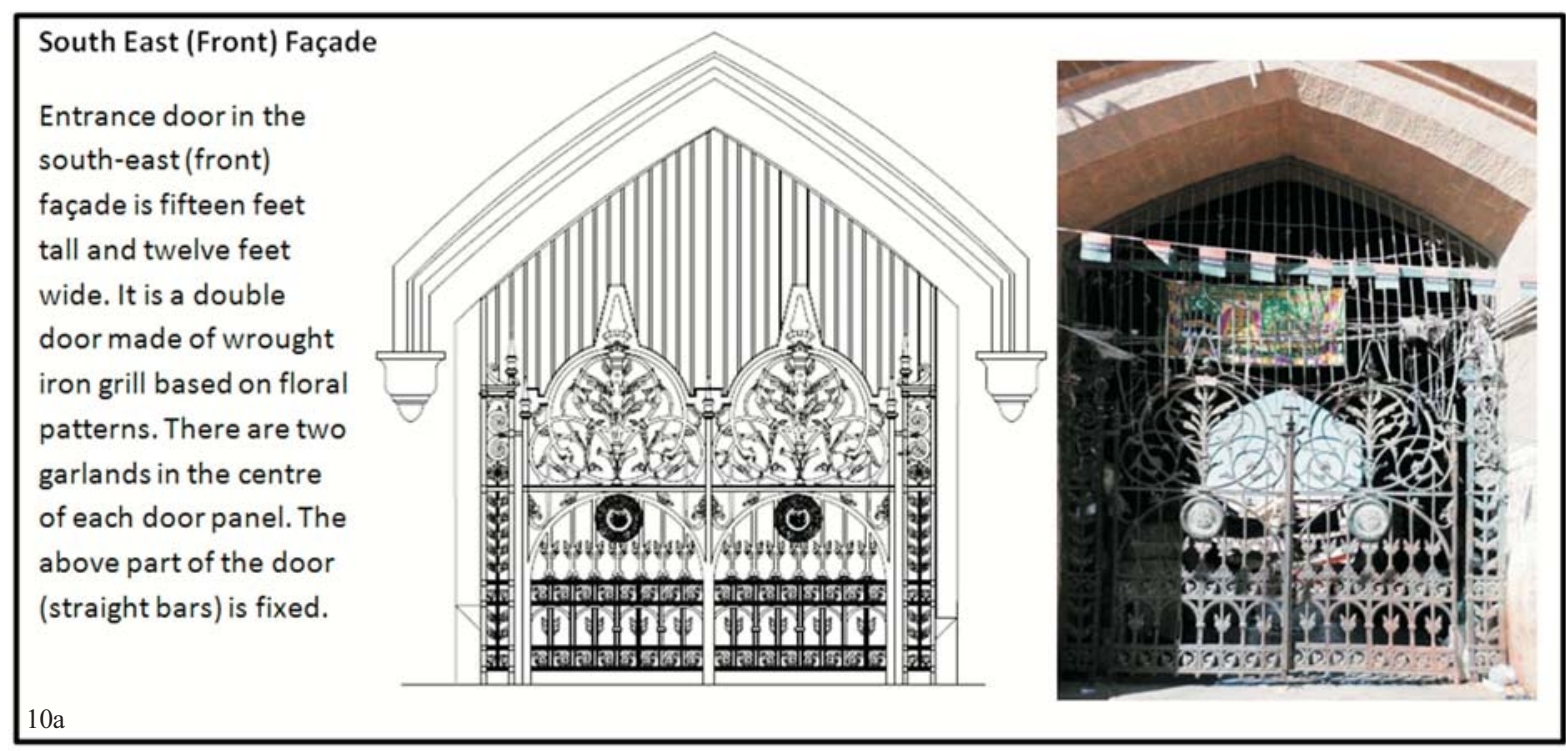

NORTHWEST (BACK) FAÇADE

Pointed arched door in northwest

(back) façade

$10 \mathrm{~b}$

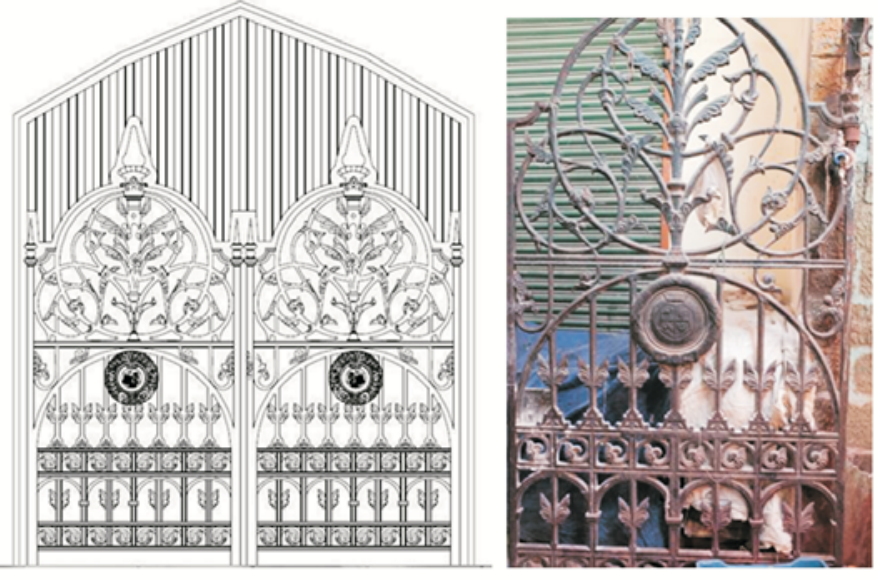

\section{NORTHEAST (RIGHT) FAÇADE}

There are special doors in the butchers section. They are installed not under the wall but at the right angle to the wall, giving more space for maneuvering. The metallic garland depicts the logo of Karachi Municipal Corporation (KMC).
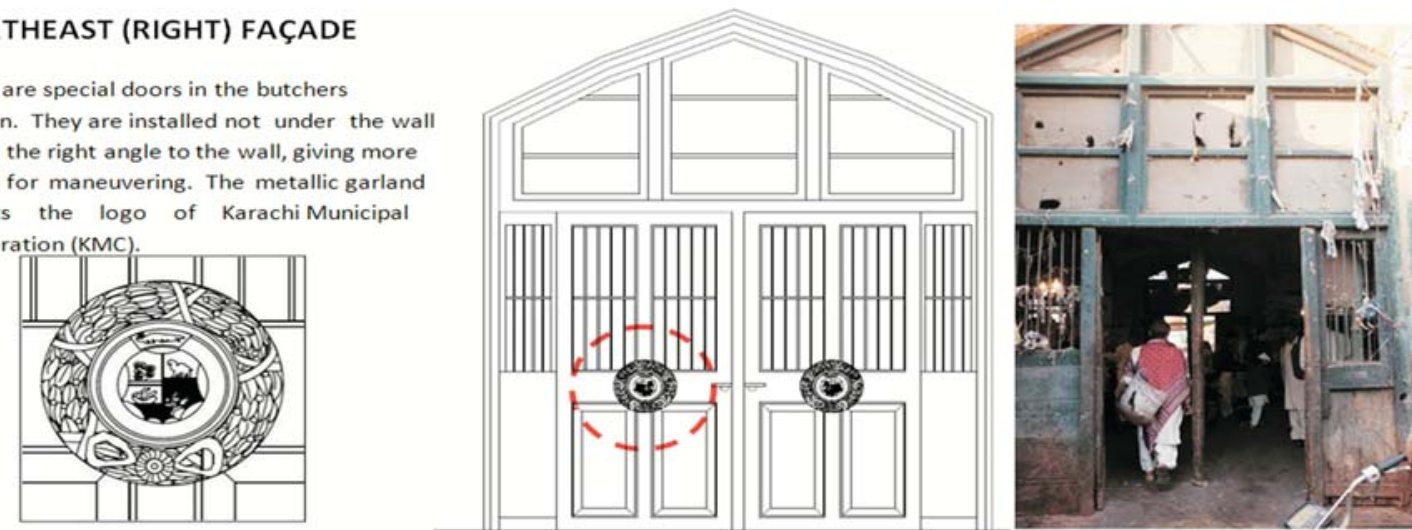

$10 \mathrm{c}$ 


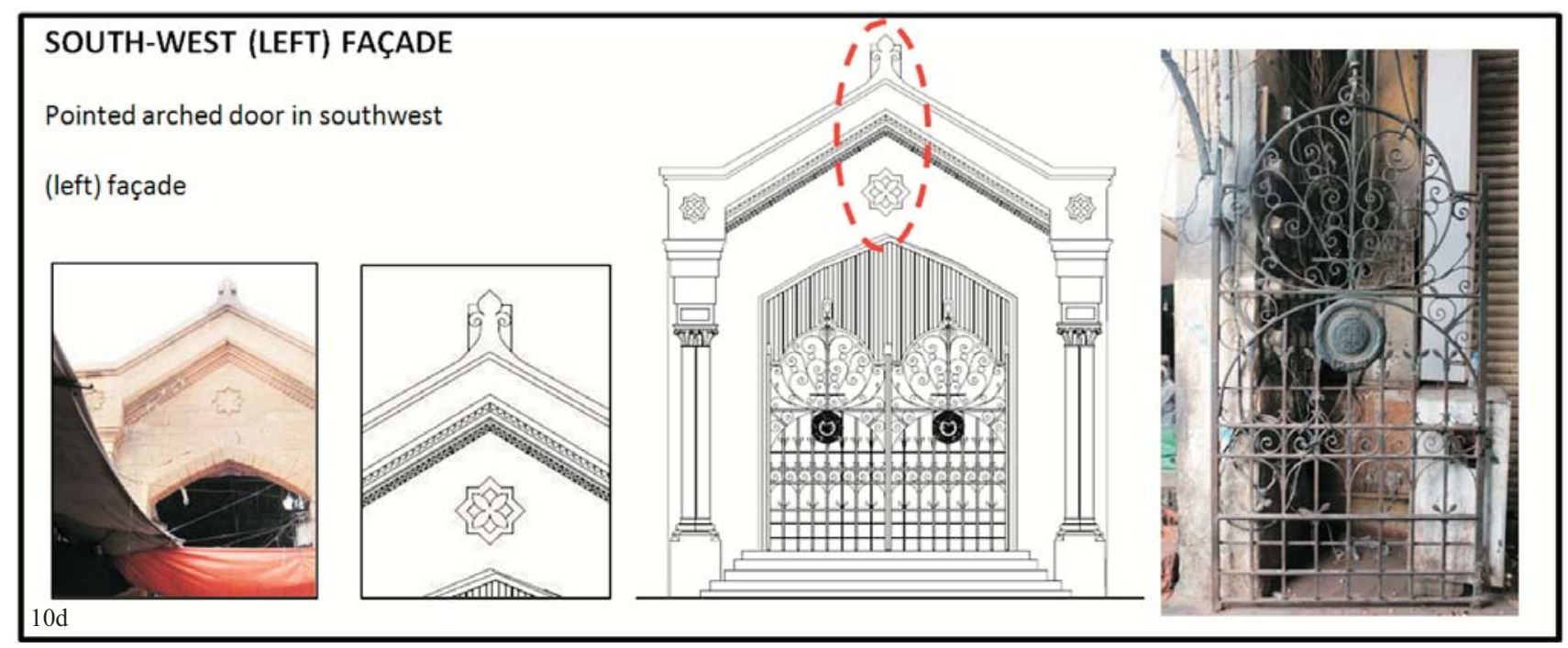

The corner chambers of the building have triple pointed arched windows separated by pilasters flanked with the Corinthian capital. These capitals are different from the ones installed in between the windows in the main façade. The windows are topped by the triple layer of the cornice made of limestone.

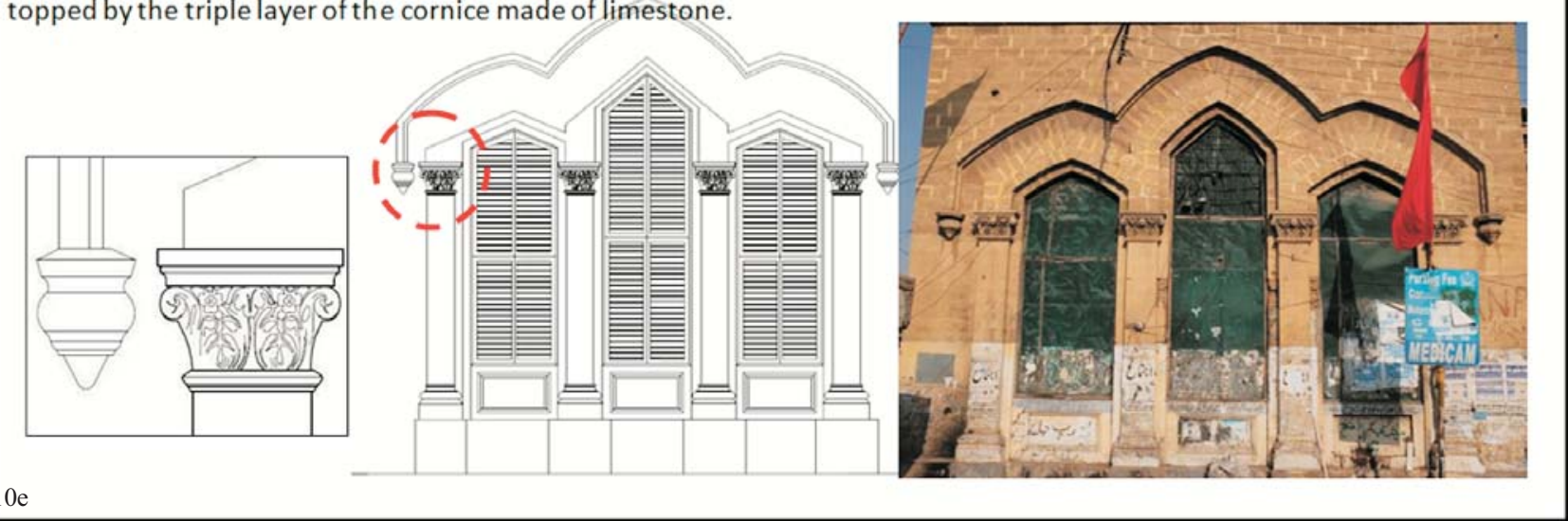

The same design of balcony exists on all four sides of the tower. The boundary wall is made up of the same material as that of the doors. Small pedestals that hold the boundary wall had pommels on top, that have been lost due to neglect.
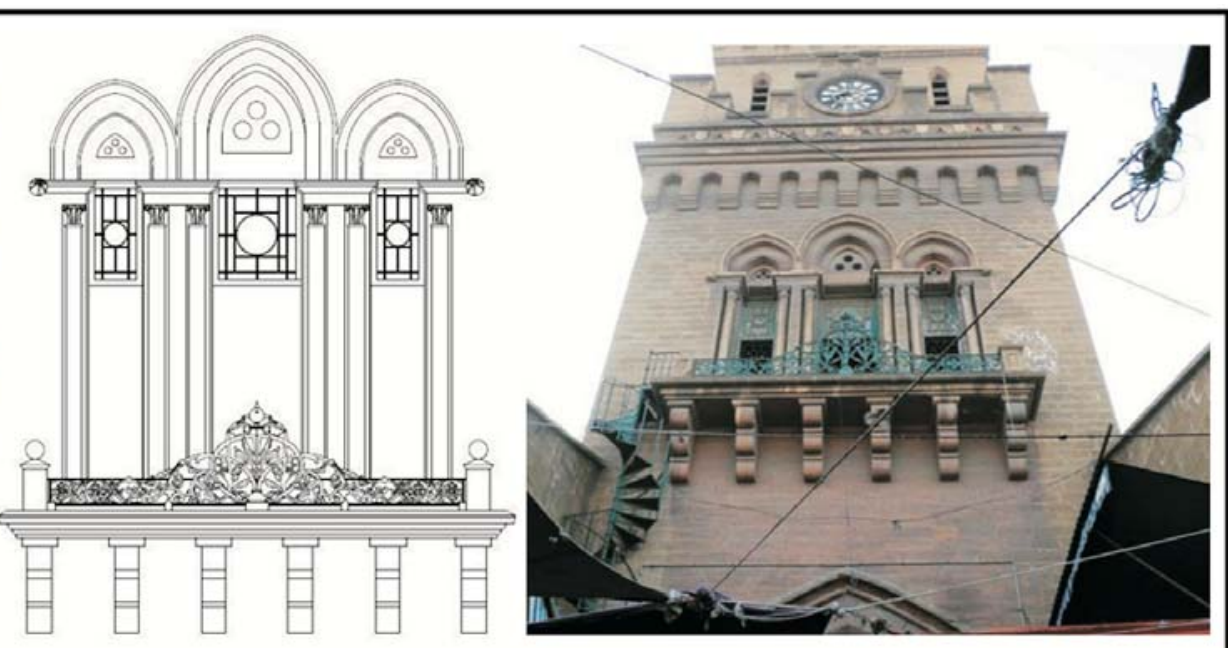

$10 \mathrm{f}$ 
Following the Gothic style of architecture all the openings of the building are of pointed shape. The façades have single pointed arched windows with wooden shutters and vertical iron grills.

$10 \mathrm{~g}$

Windows in the façades are separated by the twin pilasters topped by the Corinthian capitals decorated with acanthus leaves and scrolls. The entablature is in the form of a simple rectangular block placed in between the capitals and the cornices.

$10 \mathrm{~h}$

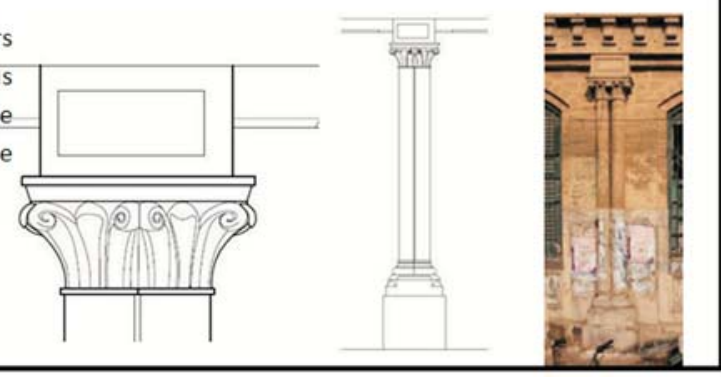

Leopard heads are found at the cornice under the tower ceiling in the four corners of the tower made of limestone. Apart from this, the building has several styles of cornices as decorated façade ornamentation.

$10 \mathrm{i}$

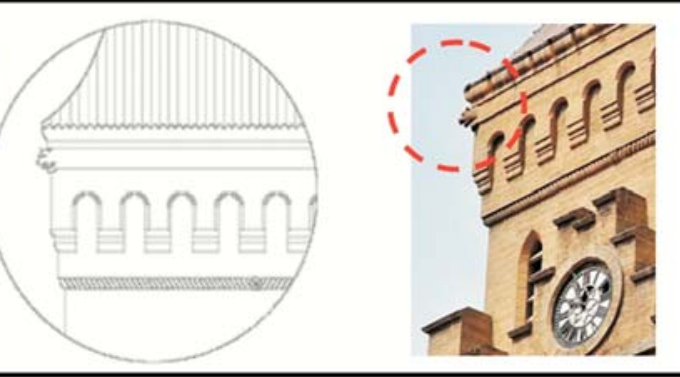

Dormer window exists on all four sides of the roof of the tower and the corner chambers. There are total of twenty dormer windows in the market building. The sizes and design is the same everywhere. The dormer windows are topped with wooden crowns.

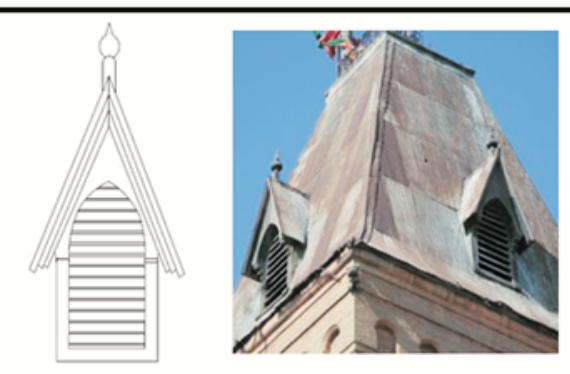

10

Flag staff post is no more existing, as seen in the image, thus a drawing was created to mark its exact location. Both the boundary wall and the post are made of wrought iron work with elaborated design based on geometrical patterns.
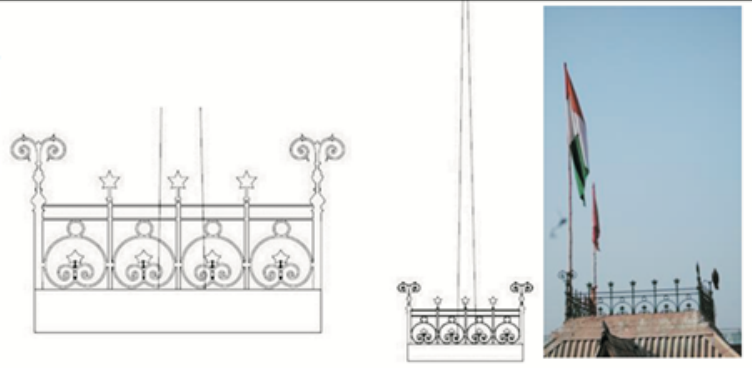

$10 \mathrm{k}$

Figure 10(a-k): Detailed documentation of different building components 


\section{ARCHITECTURAL VALUE - ANALYSIS OF THE ARCHITECTURAL DESIGN OF THE BUILDING}

\section{Shop Design}

Different sources quote different number of shops in the building (shops: 258, stalls 347 (Lari, 1996), shops: 280 (Baille, 1890). The building was primarily designed with the capacity of 280 (Lari, 1996) built shops and stalls, but over the period of time this capacity has altered. At certain locations the shops have also been split into two. Originally the shops were designed as working platforms with no canopies, (covering) and partitions in between and with a storage in the basement. They were set in a unique layout of four shops in a row, central two rows back to back and next to the walls facing each other. The shops in the front were in form of raised platforms and were set in this particular style to avoid any visual obstacle and to receive better light and ventilation. One could see the end of the wing while standing in the middle of the wing. With the passage of time the shop design has evolved. They were added with canopies and shutters. The space above the ceiling was used for dumping storage (Figure 11).

\section{Clock Tower}

As a signature style of Strachan, he designed the façades of the tower exactly the same in all four sides on a square plan, till the height of $140^{\prime}$. In general the style of the tower can be distinguished in three stages. The lower most stage is till the height of 20', consisting of a huge 12' wide pointed arched opening to allow access to the building. It is provided with decorative buttresses at the front two corners. The top level starts where the buttress ends, and the lower cornice of the balcony starts. The second stage gets narrow from the centre, however the corners are still of the same width as that of the first one. It is provided with a large chiming clock with iron dials each $6^{\prime}$ in diameter which regrettably is not working anymore. At the junction of second and last stage, small yet delicate leopard heads at each four corners of the tower confirm the finest of craftsmanship skills (Ali, 1983). The last stage of the tower culminates with a gable roof covered by the corrugated aluminium sheets and crowned by an iron grill boundary wall with floral patterns. At that point is the location for the flag post, which unfortunately fell down in 2013. The tower is accessed through a spiral staircase (Figure 12).

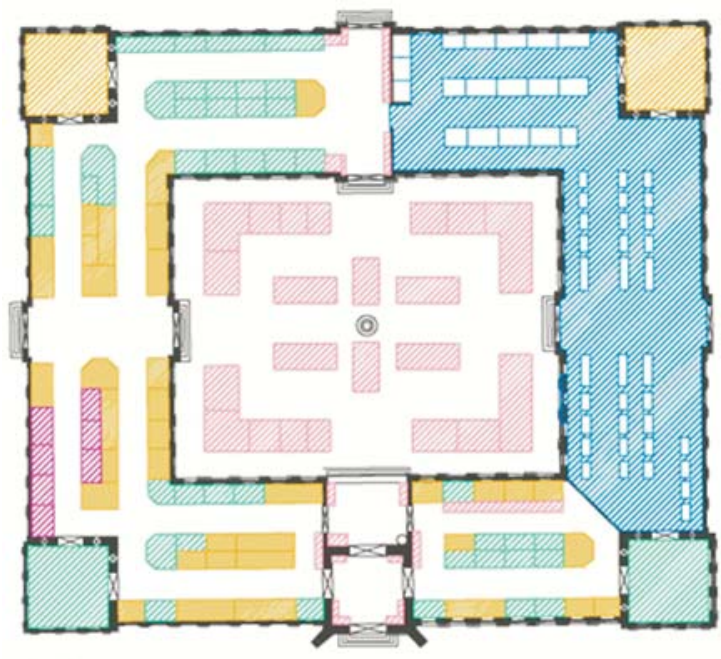

Original design - raised platform with basement

QD New design - Counter without basement

Z7 Mixed design - high platform + counter

$\mathbb{Z}$ Unidentified

Dew addition - shops constructed by means of encroachment

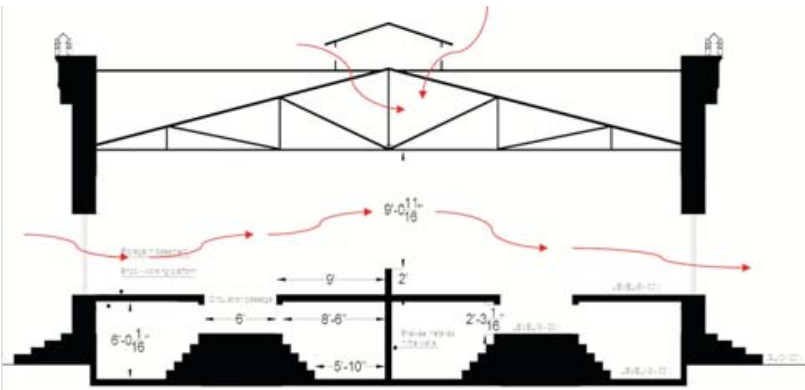

The original design included 3' raised platforms used as the working decks accessed by the steps. The shops in mid were divided by a small wall and the storage was in the basement that were closed by double shutter very small doors (like windows). This design was appropriate to have maximum exposure of natural light and air. Air circulation is marked in red color.

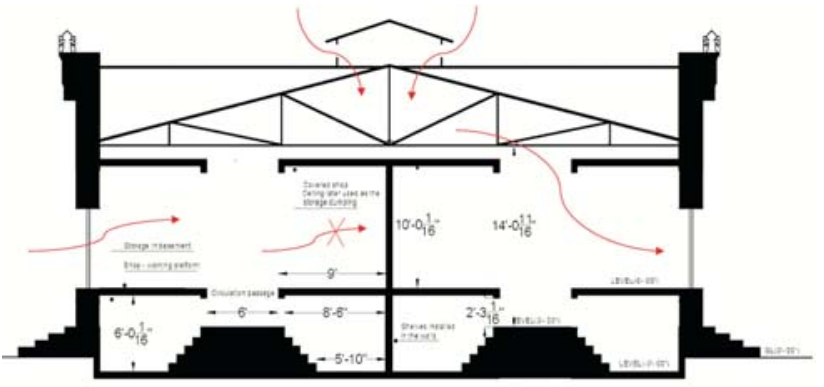

The raised platforms later were provided with covered ceilings and the shutters as most of the shops removed their basements due to rising dampness problem. The space above the ceiling was used as storage dumping. This space later was properly designed with storage cabinets. The air circulation is stopped due to the high walls of the shops.

Figure 11: Images showing the plan layout and the sections of the market. 

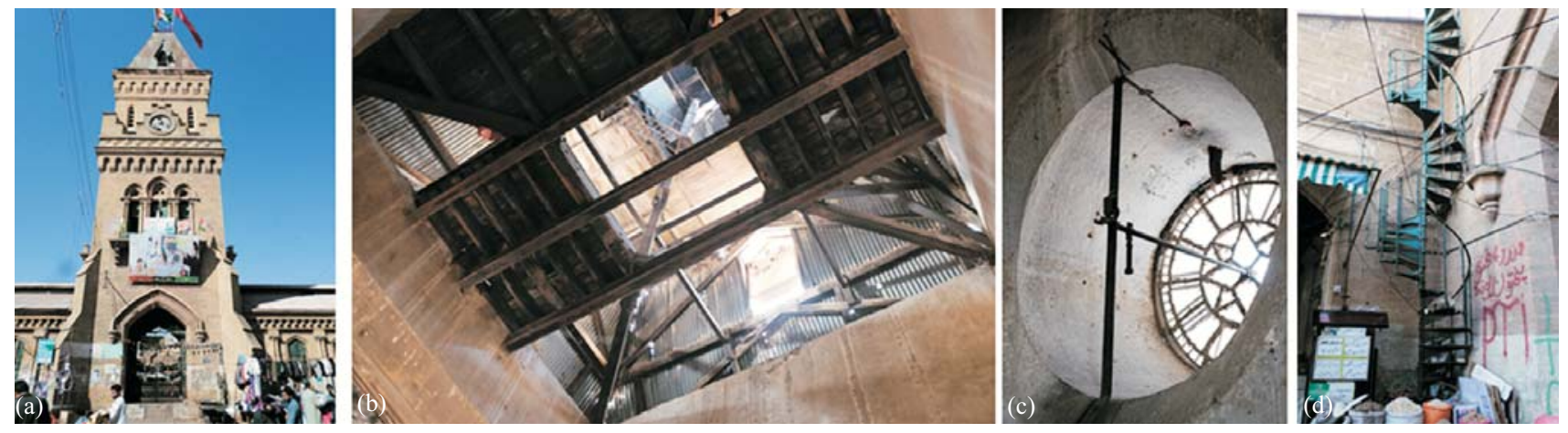

Figure 12(a-d): Images showing the details of the clock tower.

\section{Pilaster}

Usually the pilasters are used to articulate an edge of the wall but in the case of Empress Market, outer and the façades facing courtyard are ornamented with circular twin pilasters. The pilasters have round bases and are placed on top of a two leveled pedestal of almost 2' height. The top of the pilasters are flanked with the Corinthian capitals decorated with leaves and scrolls. There is split architrave in the form of a simple rectangular block placed in between the capitals and the cornices. The front and back façades of the building are divided into two parts, left and right of the entrance gates. Each of the part has six sets of pilasters and two cantons (pilaster in the corner) at a consecutive distance of 8' - 9' approx bordering the pointed arched windows on both sides of the central entrance. On the other two sides there are five sets of pilasters and two cantons on either side of the entrances (Figure 13).

\section{Courtyard}

Empress Market is a symmetrical building enclosing an area of $130^{\prime} \mathrm{X} 100^{\prime}$ as a central courtyard (Lari, 1996). The provision of courtyard indicates the influence of vernacular architecture over the Gothic style of construction (Ali, 1983).

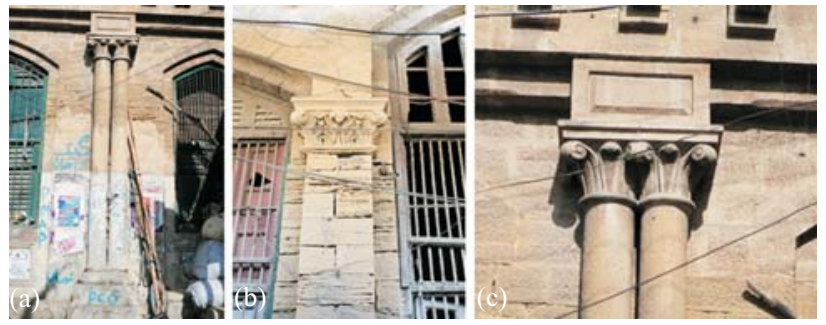

Figure 13(a-c): Images showing pilaster on the facades of the building.

The building surrounding the courtyard has four wings each 46 ' wide, connected through an entrance in the center of each wing. The floors of the courtyard used to be paved with stone blocks, that later were replaced by concrete cement tiles. At the moment the courtyard is entirely occupied by the shops. At each of the corner, shops have been added as permanent additions, whereas the rest of the open space has temporary shops like vendors. There used to be a drinking water fountain in the middle of the courtyard, which does not exist anymore. Figure 14 represents the original design of the fountain that was installed over a stepped platform to mark it as a central point of the market. Currently the space of the fountain is occupied by a tall lamp post (Figure 14).

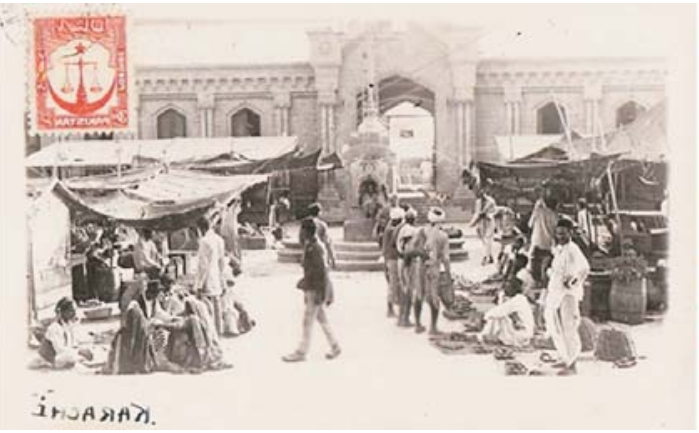

Figure 14: Images showing a drinking water fountain in center
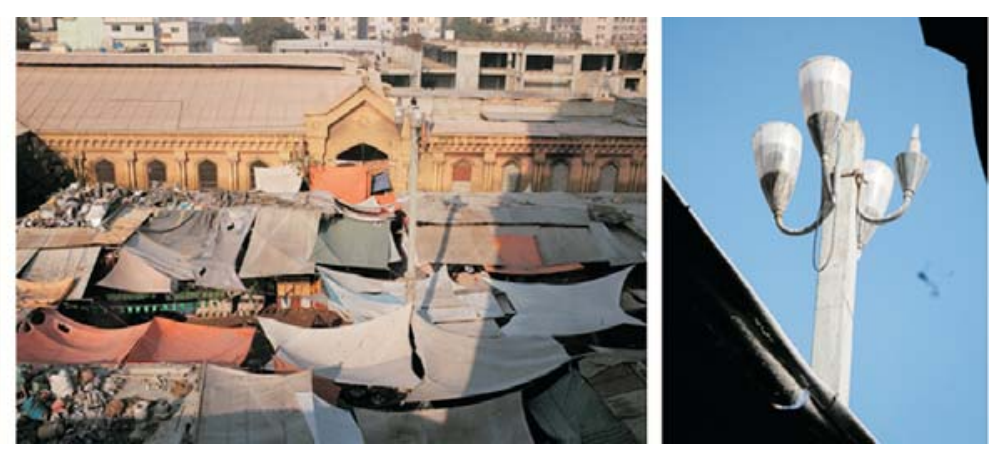

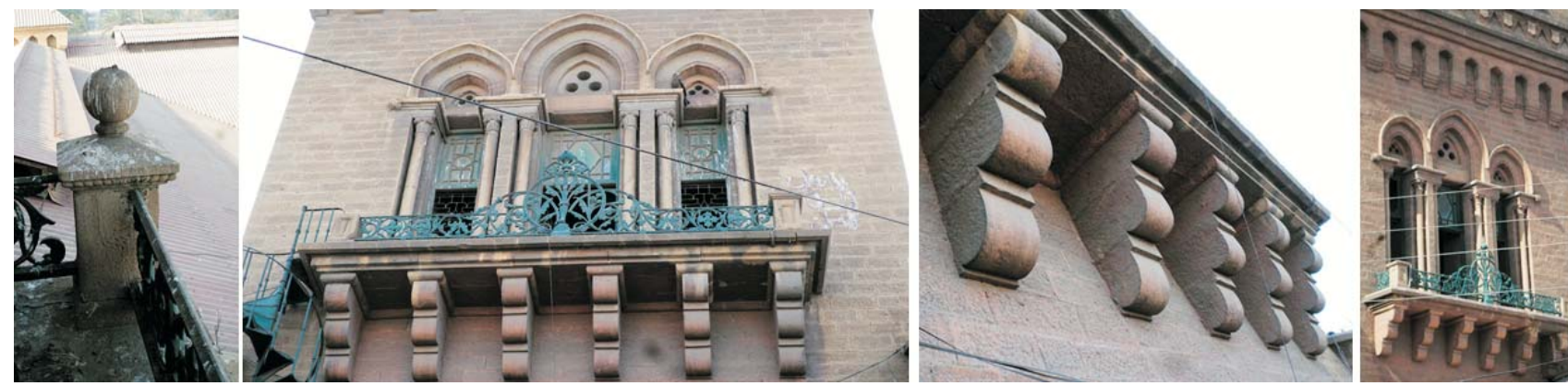

Figure 15: Images showing balcony, brackets under the balcony platform and pommel on top of the pedestal.
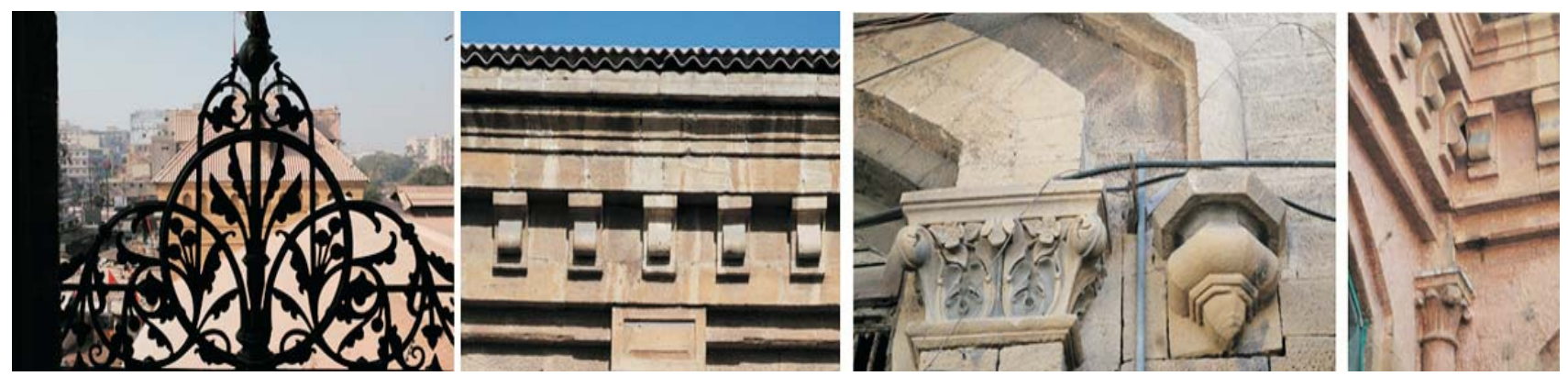

Figure 16: Images showing various ornamentation details.

\section{Balcony}

The clock tower of the Market building has four symmetrical balconies on all sides as a small platform projecting 2'-08' from the wall and supported by six stone-carved brackets. The parapet of the balcony is a 2 ' high wrought iron grill that is fixed within two stone posts of same height on either side. These stone posts are supposed to be topped by round pommels each but unfortunately only one pommel on the northwest (back) side exists. The entrance to the balcony is through a set of triple arched door openings (Figure 15).

\section{Ornamentation}

The building has minimalistic ornamentations. The noteworthy adornment is in the form of cornice moldings that are used on the façades in various styles. Cornice runs as the multiple layers of bends at the top edge of the building. The openings are crowned with similar form of cornices as that of their design. The architrave above the capitals is in split form and the frieze above is decorated with dentils. Apart from the cornices there are other small elements of interest in the building, such as the delicate leopard heads at each four corners of the tower, buttresses at the entrance, stone carved brackets and floral patterns engravings on the secondary entrance portals of the building. The corners of the entrance tower are chamfered to enhance the delicacy of the corners. Another important element of ornamentation is the use of different designs of grill iron work in doors, windows and the parapet walls of the balconies. Each of the doors has unique design of the grills, although the basic design is extracted from the leaves and scrolls patterns. All four balconies have the same design of the grill iron work but different from that of the doors (Figure 16).

\section{Pointed Arched Openings}

Following the Gothic style of architecture the entire openings of the building are of pointed shape. The façades have single pointed arched windows with wooden shutters and vertical iron grills. The corner chambers of the building have triple pointed arched windows separated by a pilaster flanked with the Corinthian capital. At the moment the original wooden shutters are removed from these triple windows and the openings are replaced by the wooden/ metallic planks, often not openable, because of the function occupied by them currently. The doors are also designed on the same pattern having the pointed arch. There are special doors in butchers' section. They are installed not under the wall but at the right angle to the wall, giving more space for maneuvering (Figure 17). 

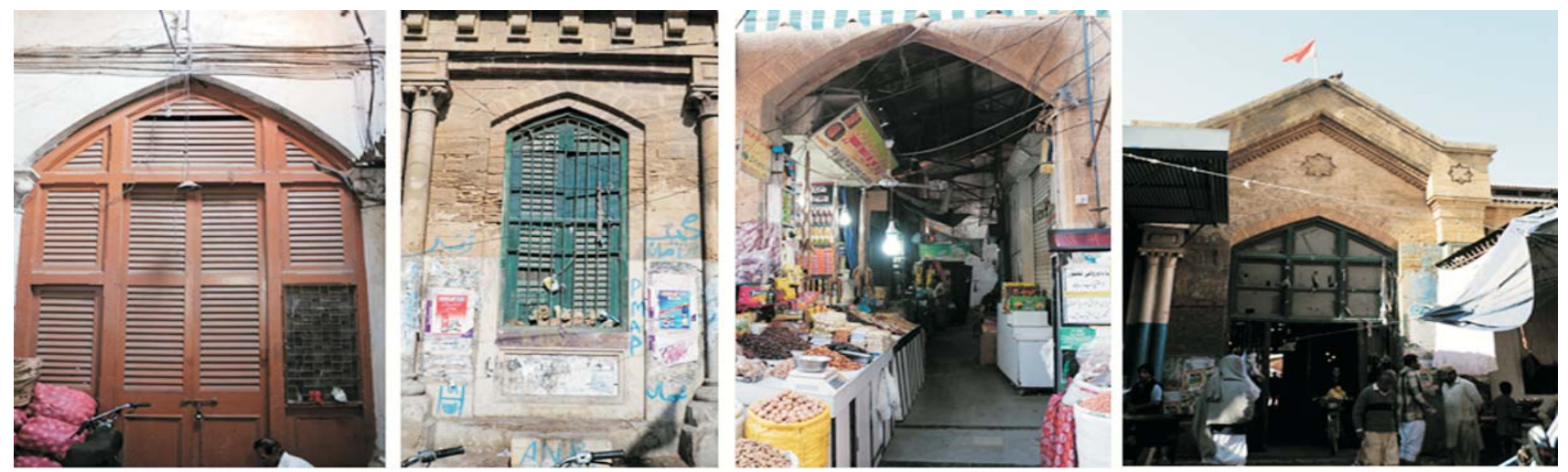

Figure 17: Images showing various pointed arched openings

\section{Interior}

Over the period of time the internal spaces have changed a lot. The walls from inside are plastered with lime plaster and painted. At certain locations cement plaster is used as an attempt of restoration. The arched openings in the corner chambers in the original design were initially open for all, but at the moment are closed and the chambers are accessed via a single opening. Chipboard is seen at various locations as the material used for closing. These arches are supported over the round columns with Corinthian capitals that are still intact and in original form except for their surface finish. The floors are redone as white and grey marble tiles with black borders. Each of the doors of the secondary entrances into the building has unique type of floral patterns and the spiral designs that differ from each other completely (Figure 18).
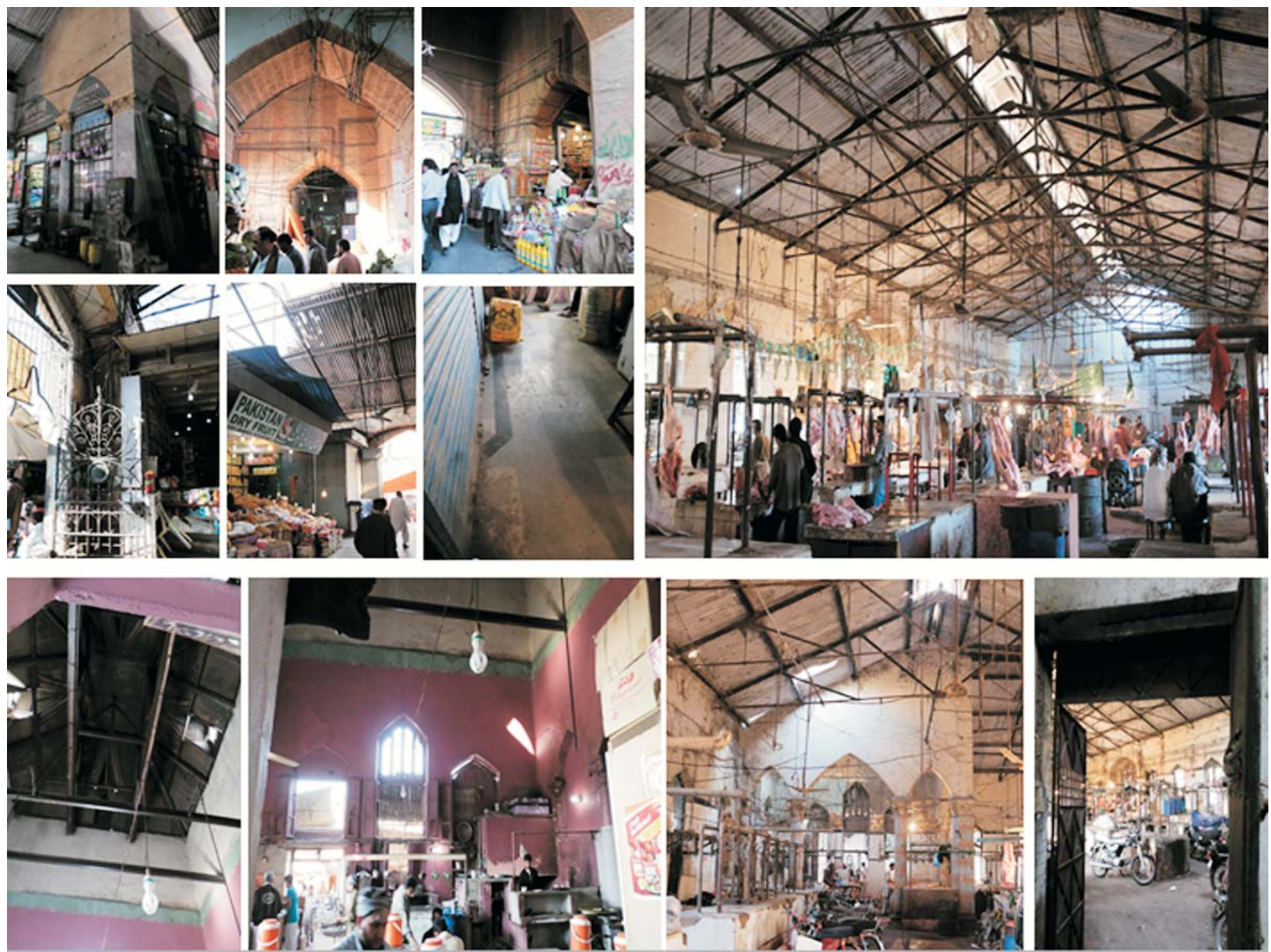

Figure 18: Images showing various location of the interior of the market building 


\section{VALUE ASSESMENT OF EMPRESS MARKET VIA APPLYING NARA GRID}

\section{Nara Grid}

The spirit of the process of documentation is totally connected with the authenticity of the buildings, and depends on the various values which bestow the feeling of this authenticity. Therefore the authenticity has been defined as a layered concept of multidisciplinary values (Balen, 2003) and Nara Grid is a tool to measure this layered concept of authenticity. Nara-grid is an evaluation scheme; to measure authenticity in terms of the multidisciplinary value systems in the framework of education and research. It was developed at the Raymond Lemaire International Center for Conservation (RLICC), at the University of Leuven based upon the 'Nara Document on Authenticity' that is a byproduct of the 'Nara Conference on Authenticity in Relation to the World Heritage Convention', held at Nara, Japan in 1994. It is based upon the 'Aspects' and the 'Dimensions' identified in the article 13 of the Nara Document that is:

"Depending on the nature of the cultural heritage, its cultural context, and its evolution through time, authenticity judgments may be linked to the worth of a great variety of sources of information. Aspects of the sources may include form and design, materials and substance, use and function, traditions and techniques, location and setting and spirit and feeling and other internal and external factors. The use of these sources permits elaboration of the specific artistic, historic, social and scientific dimensions of the cultural heritage being examined."

It basically forms an axis of six aspects, as mentioned in the article, as form and design, material and substance, use and function, tradition and technique, and the location and spirit that are measured in terms of the dimensions of the cultural heritage as artistic, historic, social and scientific dimension. Before using the grid, the cultural property needs to be well documented. Moreover the additional aspects and the dimensions can be added and the grid can be adapted or extended to the special and unique values a particular property can contain (Jaenen, 2008). The comprehensive knowledge (about the specific area to be analyzed) helps in developing a guide to future treatment and monitoring without compromising the valuable aspects of the property.

\section{The Process of Applying Nara Grid}

The template of Nara Grid is applied to the Empress Market building. Each of the aspect of the grid is analyzed with respect to each dimension which resulted in, a well-structured informative table. Initial stage of applying the grid was to acquire all the necessary information - historic and architectural. The value system associated with any historic property is often considered to be relative varying across cultures and belief systems which can further be acknowledged by an appropriate documentation.

\section{NARA GRID - APPLICATION OVER THE EMPRESS MARKET BUILDING}

\section{Form and Design}

\section{Artistic}

The plan of the Empress Market is unique for a market building; the concept follows the idea of shopping of various items under one roof. The building has minimalistic yet artistic ornamentations. The noteworthy adornment is in the form of cornice moldings that are used on the façades in various styles. Apart from the cornices there are other small elements of interest in the building such as the delicate leopard heads at each four corners of the tower, buttresses at the main entrance, stone carved brackets and floral patterns engravings on the secondary entrance portals of the building.

\section{Historic}

The form of the building refers to the domestic approach of the Gothic architectural adaptation in the colonial region of Karachi by the architect James Strachan. This is evident from the provision of an auspicious courtyard within the building which signifies the influence of vernacular architecture over the Gothic style of construction.

\section{Social}

The presence of open to sky courtyard within the rectangular form of the buildings enhances the communal feeling. It is not only used by the shop owners or the shoppers but also as a short cut to get to the other sides of the building through the intermediate entrances. Moreover, there is one tea shop inside and couple of them attached to the building, which also play a vital role in community interactions.

\section{Scientific}

Design refers to the well ventilated and well lit alleys of the market. Presence of a $140 \mathrm{ft}$. clock tower and gable roof with a proper ventilation system is an indication of the scientific approach of the craftsmen at that time. 


\section{Material and Substances}

\section{Artistic}

The masonry is done in ashlar, using fine Gizri yellow limestone. In ashlar masonry the stone blocks of same height in each course are used. Every stone is finely tooled on all sides. The moldings attached to the building are also done in the same material. The attractive patterns of grill iron work refer to the artistic approach of the craftsmanship.

\section{Historic}

Lime mortar is used as the binding material in the form of uniform thickness of joints. Outer surface of the masonry blocks is treated distinctively, referring to the early $19^{\text {th }}$ century surface finish approach in subcontinent. Each block is treated with the chisel dressing in the center and plain margins are used in outer surface finish.

\section{Scientific}

Scientific investigation of materials gives craftsmen input into the choice of materials and practices used. Use of lime mortar in internal walls is to incorporate the impact of local climate.

\section{Use and Function}

\section{Artistic}

The form of the building is based upon a conventional design of markets in British India. It is simple, less artistic yet very functional in design. Each section is properly located according to the use, such as the dry grocery item at the front and the meat section at the side wing keeping in mind the function as well as the aesthetic sense of the users.

\section{Historic}

The building has sustained its original function; it was built as a market and it still is being used as a market building. Although the use of market that was exclusively for the British elite was changed to be used by all soon after its completion.

\section{Social}

The market building is deficient in some of the very indispensable services such as the toilets. These were missing in the original design, although were added later, but not in appropriate manner and location. Toilets for women are still not there. The courtyard acts as a common meeting space for all shoppers and the shop owners. There used to be a drinking water fountain in middle of the courtyard which sadly does not exist anymore.

\section{Scientific}

The building represented a unique design of market buildings; 'a concept of under one roof shopping' in the region. Its design was contemporary to the other markets in the region.

\section{Tradition and Techniques}

\section{Artistic}

The use of various striking patterns of cornice moldings as surface ornamentation refers to an artistic approach of the craft and workmanship.

\section{Historic}

Building construction techniques used in history provide an understanding of the construction systems in use in or before $19^{\text {th }}$ century. Use of different types of natural stones as main building component forming simple load bearing or the compound walls was very common. To cope with the prevailing weather condition courtyard and the open spaces within the dwellings were commonly used.

\section{Scientific}

The design of the market building helps in understanding the construction techniques of the $19^{\text {th }}$ century architecture.

\section{Location and Setting}

\section{Artistic}

The position of Empress Market was set on a prime location on a main road making it an approachable premise from different parts of the city and worth landmark value.

\section{Historic}

Empress market was contemporary to six markets built by British at that time. It is included in the list of one of the early (first) listings in the city of Karachi. The area where the Empress Market is located was previously used as the punishment ground for the mutineers of 1857 independence war, and called as "Top Dam". 


\section{Social}

To eradicate the memory of Top Dam, the city municipal government decided to build something in its place, something that would be of universal value and accessible to all. It was decided to construct a Market to commemorate the jubilee of Her Majesty the Queen Victoria, the Empress of British India then.

\section{Spirit and Feeling}

\section{Artistic}

The building represents artistic attributes of the Gothic architecture incorporated within the domestic approach. The clock tower in the middle of the façade gives an impression of a central focal point and a feeling of symmetry, while looking at the equally distributed windows at its either sides. The enormous structure of the market building bestows a feeling of grandeur and sumptuousness.

\section{Historic}

The façades and the interiors are in need of conservation. The signs of neglect give a feeling of abandonment. The high gable roofs display a character of elegance.

\section{Social}

The interior of the building gives a lost spirit of openness and natural lightness due to the change in the style of shops and also due to the encroachments within the shops. It shows neglect in some of the parts of the building and the loss of original features, giving a run down impression that can be mended by small interventions.

\section{Additional Value}

Apart from the six aspects of Nara Grid, 'Accessibility and Visibility' is taken as an additional value to be added in the grid. For a landmark building accessibility and visibility is of utmost importance for its significance and for the sustenance of its function. In case of the Empress Market this concept can be viewed as the direct and easy ability to access it through various forms of transportation from each corner of the city. Therefore along with the rest of six important aspects of value, it is also considered as a unique value.

\section{Accessibility and Visibility}

\section{Artistic}

The form of the building is designed to be well connected with the surrounding markets to have a homogeneous commercial activity in and around it. Apart from the main entrance, each of the four wings of the building has their own entrance which permits the building to be a well accessed property.

\section{Historic}

The British built separate settlements next to the native walled city; Saddar Bazaar is one of them. The quarter developed as a thinly populated low-rise settlement, with wide thoroughfares, green space and little plantation with Empress Market erected on a large open land with a 140' tall clock tower. Due to its location within a low rise neighborhood it was visible from far.

\section{Social}

The Empress Market is referred to as having a landmark value due to its magnificent structure. It's a hub of Karachi's mercantile associations.

The above mentioned aspects helped in identifying the value of the building from artistic, historic, social and scientific perspective. Empress Market is one of those structures that has managed to stay intact and avoid destruction, vandalism, and other damages through natural and manmade disasters. It has however seen the neglect and change in attitudes and has been subjected to go through difficult changes. The building has however sustained the architectural and the landmark value, unlike the ambiance and the surrounding environment that has degraded over the period of time. The existing neighborhood landscape itself requires improvement in order to render it more pleasing to the eye, artistically more desirable, and functionally superior.

\section{CRITICAL REVIEW ON THE AUTHENTIC VALUE OF THE BUILDING}

The discussion on the authenticity and value of the building cannot be restricted to the economic or market value in isolation, the context of the historic structure also forms an integral part. The values attributed to the building are not only related to the philosophical notions of its construction, 
but the public value in the overall neighborhood setting of it. In the case of the Empress Market the economic value of the building remains high despite its old character. The central location has kept the flow of customers consistent through the decades of city growth, which maintained the economic values of properties in and around the building. The complex ownership structure however, has kept the investments in maintenance to minimal. The occupants always look towards Karachi Municipal Corporation (KMC) for major maintenance and that has not proved well for the actual structure.

The social value of the building is a reflection of the overall condition of the quarter itself. Saddar Bazaar used to be an intellectual and an entertainment center of the city as most of the refuge population (1947 and onwards) came to live in the city which offered all sorts of activities, from financial to cultural. It housed number of coffee houses, bookstores, cinemas, dancing schools, theatres, pubs, clubs, etc., where the intellectuals, artists, writers, poets and people from various disciplines had their shared interactions. This enriched Karachi in cultural terms. Regrettably the present-day state of the area is entirely different from what it used to be and it lacks in social interactions. This has had an impact on the building's social standing and it has now been reduced to a whole-sale market and is generally targeting the costconscious segment of customers. This is quite a change from its heydays.

The Empress Market building also portrayed a strong notion of community cohesion. There is a number of old generation shopkeepers in the building that have seen the market grow to its present day appearance. Further investigation lead to identification of few old shop owners in Empress Market who willingly shared their memories and views about the market. One such account suggests that since it was one of the first covered shopping spaces, therefore the dwellers not only were facilitated by this service, but they took pleasure in the idea of shopping and relaxing under covered shade. According to them, it not only served the people related to the market but it was used as a common communal space too. Due to its access from all four sides, it created a cross axis which was used by the passer-by as a shortcut to reach to the other side of the market. In other words, it was a combined approach of a rational and a modernist intellect with an attention towards domestic features of interest. The openings are still there but due to the added markets to the outer building façades that axis is gone. They also lamented that the charm of the market has been lost long ago. Now a days there is struggle for basics, for instance the building does not even have water supply connections for shop keepers.

\section{NARA GRID AND ITS ASSESSMENT}

The use of Nara Grid assessment helps to disaggregate the value of Empress Market through a prism of various aspects. It makes a strong case for the value of the building as a historic and significant monument for the city of Karachi and its residents.

Some of the most prominent aspects of the building that come out of the structured Nara grid include its successful design, the seamless amalgamation of western and eastern styles and their ability to provide something uniquely local and of high functional value. The social-historic value that it has brought to the residents of Karachi right from its beginning to this day, embeds it in the socio-cultural fabric and the architectural landscape, making it inseparable from the city itself. Thus, any description of the building cannot stand separate from the broader narrative of the city and its historic or recent conditions.

The exquisite design by the architect successfully eradicated the violent memory of the location. It achieved its stated objectives to create a fresh memory which is opposite to its earlier reputation. It became a public place, albeit gentrified in the beginning, and of high functional utility to a wide segment of the society.

The building is important in defining the vernacular influence on a European architectural style in present-day Pakistan, though the 'localization' of Gothic style had already started in other parts of British India. The local considerations of keeping up with the warm weather helped evolve a design which focuses on good ventilation and access to the natural lighting. It is also important to note the 'communal' feel of the design where various wings of the covered market were connected through a common central courtyard, creating a right blend of modernity with the tradition. The concept of shopping 'under one roof', though contemporary to a few other modern markets at that time, was still new.

The use of Jodhpur stone provides a certain imperial character to the building and helps it rightfully boast the name that it carries. Stone was adopted by British to solidify their imperial power in the minds of the locals as it provided them the ability to erect rather large structures. The tall clock tower thus provides the building a landmark and visibility value, depicting full confidence of a colonial 
master. It is only in later half of $20^{\text {th }}$ century that the tower had been eclipsed by high rise buildings in the vicinity that this particular aspect lost its impact.

The building still carries high value in the story of Karachi and lives of its residents. The fact that it has retained its original function, helps provide a consistency in its mental image and thus amplifies the other characteristics of the building, particularly its landmark value. It now stands as an indispensable historical, physical, and mental landmark, with a remarkable consistency, across the generations of residents of the city. It brings a unique mix of nostalgia, pride, and functionality in the minds of those who are associated with it directly as customers or shop keepers, or indirectly as the residents of the city of Karachi. It has featured in countless chronicles of the city and it continues to do so to this day. With the proliferation of social media, the building has gained further momentum.

\section{CONCLUSION}

This whole exercise of the value analysis was concluded to understand the value system associated with the market building and the variation of this value system for various stakeholders and the users. The building has sustained its original worth as a landmark monument that reflects the British colonial supremacy, except for the degradation of the environment within its immediate context.

Empress Market which used to be a jewel in the crown of the city reflects today's socially fragmented ambience of Saddar Bazaar, which is an outcome of the process of gentrification, a process that changed the customer profile from high to low end. Its value remains tied to its surrounding and broader issues of urbanization in the city of Karachi. The unplanned management of the commuters has led to the present-day transit state of the whole quarter, affecting the value of the building negatively. Commercialization pressures on land and low-rise buildings continue to alter the environment in which Empress Market is surviving, while the need for protecting the built heritage, in general, remains indispensable.

\section{REFERENCES}

Ali, F.I., 1983, Revitalization of Empress Market, B.Arch Thesis, DAP-DCET, Karachi.

Archives 150, Viewed 10-09-2016, from https://www.facebook.com/archive150.

Balen, K. V., 2003, "From Conservation Principles to Materialization (Or the Other Way Around: How Is Materialization Guided by Principles?), in Consolidation of Masonry", Advances in Materials Science and Restoration, Volume I, Ed. D. Van Gemert Freiburg: Aedification Publishers, Belgiom.

Bailie, A. F., 1890, Kurrachee: Past, Present and Future (Volume II), Pakistan Herald Publications (PVT) Ltd., Karachi

Jaenen, A., 2008, "Safeguarding the Spirit of an Historic Interior on the basis of the 'Naragrid', 16the General Assembly of ICOMOS Quebec 2008”, viewed April 032015 from, http://www.international.icomos.org/quebec2008/cd/toindex/77_pdf/77j1F6-282.pdf

Lari, Y., 1996, The Dual City: Karachi During the Raj, Oxford University Press with collaboration of Karachi Heritage Foundation.

Tidwell, S., 2002, “Assessing the Values of Cultural Heritage, The Getty Conservation Institute”, The J. Paul Getty Trust Publishers.

Soomro, T., 2015, 'Revival of Forgotten Heritage: Conservation of Empress Market and Revitalization of its Historic and Social Context', Masters Thesis, KU Leuven, Belgium. 